$\frac{\text { PNL-8039 }}{\text { UC-800 }}$

\title{
The Utility of System-Level Ram Analysis and Standards for the U.S. Nuclear Waste Management System
}
S. R. Rod
M. D. Adickes
B. K. Paul

March 1992

Prepared for the U.S. Department of Energy under Contract DE-AC06-76iLLO 1830

Pacific Northwest Laboratory

Operated for the U.S. Department of Energy

by Battelle Memorial Institute 


\title{
DISCLAIMER
}

This report was prepared as an account of work sponsored by an agency of the United States Government. Neither the United States Government nor any agency thereof, nor Battelle Memorial institute, nor any of their employees, makes any warranty, expressed or implied, or assumes any legal liability or responsibility for the accuracy, completeness, or usefulness of any information, apparatts, product, or process disclosed, or represents that its use would not infringe privately owned rights. Reference herein to any specific commercial product, process, or service by trade name, trademark, manufacturer, or otherwise does not necessarily constitute or imply its endorsement, recommendation, or favoring by the United States Government or any agency thereof, or Battelle Memorial Institute. The views and opinions of authors expressed herein do not necessarily state or reflect those of the United States Covernment or any agency thereof.

\author{
PACIFIC NORTHWEST LABORATORY \\ operated by \\ BATTELLE MEMORIAL INSTITUTE \\ for the \\ UNITED STATES DEPARTMENT OF ENERGY \\ under Contract DE-ACO6-76RLO 1830
}

Printed in the United States of America

Available to DOE and DOE contractors from the

Office of Scientific and Technical Information, P.O. Box 62, Oak Ridge, TN 37831; prices available from (615) 576-8401. FTS 626-8401.

Available to the public from the National Technical Information Service, U.S. Department of Commerce, 5285 Port Royal Rd., Springfield, VA 22161. 
PNL- -8039

DE92. 011916

THE UTILITY OF SYSTEM-LEVEL RAM ANALYSIS

AND STANDARDS FOR THE U.S. NUCLEAR WASTE

MANAGEMENT SYSTEM

S. R. Rod

M. D. Adickes

B. K. Paul

March 1992

Prepared for

tile U.S. Department of Energy

under Contract DE-ACO6-76RLO 1830

Pacific Northwest Laboratory

Richland, Washington 99352 


\section{EXECUTIVE SUMMARY}

The Department of Energy (DOE) Office of Civilian Radioactive Waste Management (OCRWM) is responsible for developing a system to manage spent nuclear fuel and high-level radioactive waste in accordance with the Nuclear Waste Policy Act of 1982 and its subsequent amendments.

Pacific Northwest Laboratory (PNL) is assisting OCRWM in its investigation of whether system-level reliability, availability, and maintainability (RAM) requirements are appropriate for the waste management system and, if they are, what the appropriate form should be for such requirements. Based on the results of a literature search, a facility survey, and RAM modeling of the waste management system, PNL offers the following recommendations:

- System-level RAM standards and analyses should be considered as appropriate aids in designing the waste management system. They can be valuable early in the system definition and design processes as long as they accurately reflect the state of knowledge about the system.

- Fundamental system performance objectives (e.g., the most basic schedules, waste priority/acceptance criteria, throughput, dose limits, cost targets) should be established before system-level RAM standards are written. However, system-level RAM-type analys is can be a valuable tool when applied early to help establish practical system performance objectives.

- System-7evel RAM standards should be few and concisely stated. For each major systen element (e.g., individual facilities), an overall availability standard should be set. More detailed RAM analysis can then be used to help design smaller system components in conformance with system-level standards.

- Detailed RAM analysis for the waste management system is not irmediately necessary in view of ongoing work to further define the rasic system configuration and performance objectives. Detailed RAM analysis must proceed in an iterative manner in conjunction with system design through increasing levels of specificity.

- DOE does not need to develop generic RAM tools and guidance materials. Ample resources (instructional materials, computer programs, analytical services) are available. RAM models tailored to the waste management system should be developed from available generic tools. 
Most of the RAM studies done on large, complex systems are part of either classified government projects or business-sensitive industrial projects. Little documentation is publicly available, but several organizations, including architecture and engineering firms, construction contractors, electrical utilities, and industry groups, were willing to describe their experience with system-level RAM standards and analyses. The consensus among the surveyed organizations follows:

- System reliability, availability, and maintainability should be considered from the start of a project as part of good engineering practices.

- RAM standards created at a project's conceptual stage are typically few and broadiy stated, and should be derived directly from basic operational objectives.

- RAM requirements established at any subsequent design stage must be derived from the system or subsystem operational objectives.

- A clear, logical, rational hierarchy of RAM requirements must be maintained, with each level of RAM standards derived from those of the next higher level.

- RAM analysis is more general, qualitative, and varied in its application at early phases of major systems development projects than at later design stages.

- RAM analysis is appropriate only to the level of detail for which adequate supporting data are available. 


\section{CONTENTS}

EXECUTIVE SUMMARY . . . . . . . . . . . . . . . . . . . . ACRONYMS AND ABBREVIATIONS .................... . . ix

1.0 INTRODUCTION . . . . . . . . . . . . . . . . . . . . 1.1

1.1 OBJECTIVES . . . . . . . . . . . . . . . . . 1.1

2.0 CONCLUSIONS AND RECOMMENDATIONS . . . . . . . . . . . . . . . 2.1

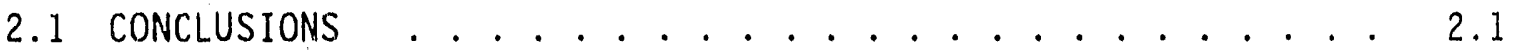

2.2 RECOMMENDATIONS . . . . . . . . . . . . . . . . 2.3

3.0 LiTERATURE SEARCH . . . . . . . . . . . . . . . . . . . . 3.1

3.1 RAM GUIDELINES AND RAM ANALYSIS TOOLS . . . . . . . . . 3.1

3.2 RAM DATA . . . . . . . . . . . . . . . . 3.2

3.3 RAM EXPERIENCE . . . . . . . . . . . . . . . 3.2

4.0 SURVEY OF ORGANIZATIONS AND FACILITIES . . . . . . . . . . . . . . 4.1

4.1 COGEMA INC. AND NUMATEC INC. . . . . . . . . . . . 4.?

4.1.1 French Spent Nuclear Fuel Reprocessing . . . . . . . 4.2

4.1.2 French Nuclear Waste Disposal . . . . . . . . . . . 4.4

4.2 U.S. DEPARTMENT OF ENERGY . . . . . . . . . . . . . . . . 4.4

4.2.1 The U.S. Nuclear Waste Management System . . . . . 4.5

4.3 WEST VALLEY NUCLEAR SERVICES CORPORATION . . . . . . . . . . 4.5

4.4 GENERAL ELECTRIC CORPORATION MOPRIS OPERATION . . . . . . . . 4.7

4.5 U.S. NUCLEAR REGULATORY COMMISSION . . . . . . . . . . . 4.8

4.6 NUCLEAR INDUSTRY ORGANIZATIONS . . . . . . . . . . . . . . . 4.8

4.7 WESTINGHOUSE ELECTRIC CORPORATION . . . . . . . . . . 4.10 
4.8 MITRE CORPORATION . . . . . . . . . . 4.10

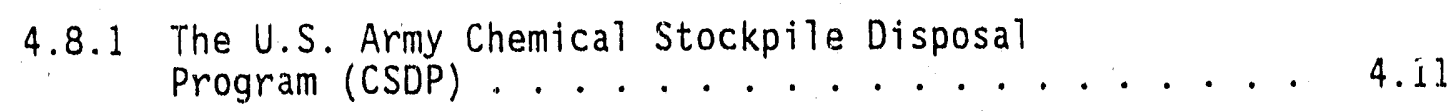

4.9 RALPH M. PARSONS COMPANY . . . . . . . . . . . . 4.13

4.9.1 The U.S. Army Chemical Stockpile Disposal . . . . . . . . . . . . . . . . .
Program (CSDP) . .

4.10 BECHTEL GROUP INCORPORATED . . . . . . . . . . . 4.15

4.10.1 Power, Refinery, and Manufacturing Systems . . . . 4.15

5,0 SYSTEM-LEVFL RAM MODEL AND ANALYSIS OF THE U.S. NUCLEAR WASTE

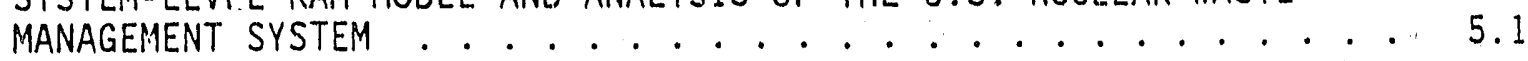

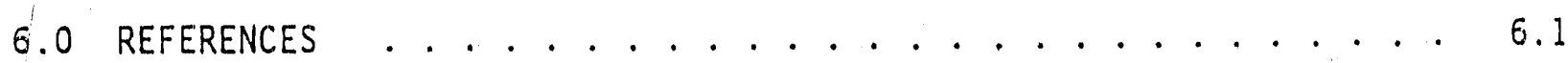

7.0 BIBLIOGRAPHY . . . . . . . . . . . . . . . . . . 7.1

APPENDIX A - MISCELLANEOUS BACKGROUND INFORMATION . . . . . . . . A.1

APPENDIX B - RAM CALCULATION SAMPLE RESULTS . . . . . . . . B. B 


\section{FIGURES}

2.1 Simplified Flowchart of the RAM Process . . . . . . . . . . 2.2

4.1 Flowchart of the U.S. Army's Chemical Munitions Demilitarization

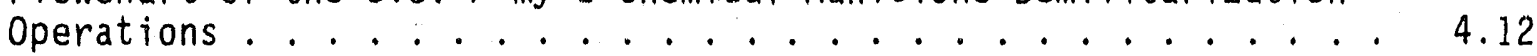

B.1 Level 1 Functional Flow Diagram for the Basic MRS Waste Management System . . . . . . . . . . . . . . B.2

B.2 Basic Waste System Level 0 RAM Model . . . . . . . . . . . . . B.3

B.3 MRS Availability Analysis . . . . . . . . . . . . . B.5

B.4 Waste Generator/MRS Transport Availability Analysis . . . . . . . B.6

B.5 Waste Generator/MRS Transport 0\% Availability . . . . . . . . . B.7

B.6 MRS/Repository Transport 0\% Availability. . . . . . . . . . B.8

TABLE

4.1 Sources of RAM Information .................. 4.2 


\section{ACRONYMS AND ABBREVIATIONS}

\begin{tabular}{|c|c|}
\hline A\&E & Architectural and engineering \\
\hline CAMDS & Chemical agent munitions disposal system \\
\hline CEA & French Atomic Energy Agency \\
\hline $\mathrm{CHB}$ & Container handling building \\
\hline CSDP & Chemical stockpile disposal program \\
\hline DOE & U.S. Department of Energy \\
\hline EPRI & Electric Power Research Institute \\
\hline FMEA & Failure modes and effects analys is \\
\hline GE & General Electric Corporation \\
\hline HLW & High-level radioactive waste \\
\hline IAEA & International Atomic Energy Agency \\
\hline INEL & Idaho National Engineering Laboratory \\
\hline ISFSI & Independent spent fuel storage installation \\
\hline JACADS & Johnston Atoll Chemical Agent Disposal System \\
\hline LWR & Light water reactor \\
\hline MOB & Main demilitarization building \\
\hline MRS & Monitored retrievable storage \\
\hline MTU & Metric ton uranium \\
\hline NPRDS & Nuclear Plant Reliability Data System \\
\hline NRC & U.S. Nuclear Regulatory Commission \\
\hline NSSS & Nuclear steam supply system \\
\hline NWPA & Nuclear Waste Policy Act \\
\hline OCRWM & Office of Civilian Radioactive Waste Management \\
\hline OECD & Organization for Economic Cooperation and Development \\
\hline
\end{tabular}




$\begin{array}{ll}\text { PNL } & \text { Pacific Northwest Laboratory } \\ \text { RA } & \text { Probabilistic risk assessment } \\ \text { PHR } & \text { Pressurized water reactor } \\ \text { RAM } & \text { Reliability, availability, and maintainability } \\ \text { RESAR } & \text { Reference safety analysis report } \\ \text { PHR } & \text { Residual heat removal } \\ \text { RIP } & \text { Ralph M. Parsons Company } \\ \text { SW } & \text { Southwest Research Institute } \\ \text { WVNSC } & \text { West Valley Nuclear Service Corporation }\end{array}$

$x$ 


\subsection{INTRODUCTION}

The U.S. Department of Energy (DOE) Office of Civilian Radioactive Waste Management (OCRWM) is responsible for developing a system for managing highlevel radioactive waste and spent fuel in accordance with the Nuclear Waste Policy Act (NWPA) of 1982 and its subsequent amendments. OCRWM responsibilities include integrating and coordinating the design and development of system elements to ensure that they can be deployed on schedule, achieve reliable system performance, and meet cost objectives.

Pacific Northwest Laboratory (PNL) $)^{(a)}$ is assisting OCRWM in investigating whether a system-level operational reliability requirement is appropriate for the national radioactive waste management system and, if it is, in defining the appropriate form for such a requirement.

\subsection{OBJECTIVES}

The goals of this investigacion were to determine whether reliability, availability, and maintainability (RAM) standards at the system level are useful and/or necessary for the waste management system to meet its performance objectives and to describe the appropriate RAM standards and how they should be applied. This report describes the results of three activities that have been conducted to date: 1) a system-level RAM literature search (described in Section 3.0), 2) a survey of organizations and facilities that have performed RAM analyses and/or set high-level RAM standards (Section 4.0), and 3) preliminary RAM calculations performed on a model of the U.S. nuclear waste management system as it is presently envisioned (Section 5.0 and Appendix B). Conclusions and recommendations can be found in Section 2.0, while survey resources are contained in Appendix $A$.

The literature search and facility survey were conducted to identify nuclear-related organizations and facilities that have incorporated RAM

(a) Pacific Northwest Laboratory is operated for the U.S. Department of Energy by Battelle Memorial Institute under Contract DE-ACO6-76RL.. 1830. 
standards into their design and to assess how RAM standards can assist waste management factlities in meeting their performance objectives. 


\subsection{CONCLUSIONS AND RECOMMENDATIONS}

The consensus of the cognizant engineers, analysts, and project managers interviewed in the course of this study was that large projects can benefit from consideration of RAM issues in the early stages of development. While early RAM standards will necessarily be general and qualitative, early consideration of RAM issues is considered to be good engineering practice. The degree of detail of resulting RAM standards should match the degree of completion of the overall design. All the organizations that regularly include RAM analysis and/or RAM standards in their system design procedures cutlined a RAM process similar to the one shown in Figure 2.1 (Guthrie et al. 1988a).

\subsection{CONCLUSIONS}

The points of consensus on complex, multiple-facility system development that emerged from this study are these:

- System reliability, availability, and maintainability should be considered from the start of a project. Consideration of RAM issues is part of good engineering practice.

- RAM standards created at a project's conceptual stage should typically be few, broadly stated, and derived directly from basic mission statements (e.g., schedule, throughput, safety, and economic objectives).

- RAM requirements established at any subsequent design stage must be derived from the system or subsystem operational objectives (schedute, throughput, safety, cost).

- A clear, logical, rational hierarchy of RAM requirements must be maintained, with each level of RAM standards derived from those of the next higher level:

- mission statement and operational objectives for the overall system

- system-level RAM requirements (pertaining to interacting facilities)

- facility-level RAM requirements

- RAM standards for major plant operations 


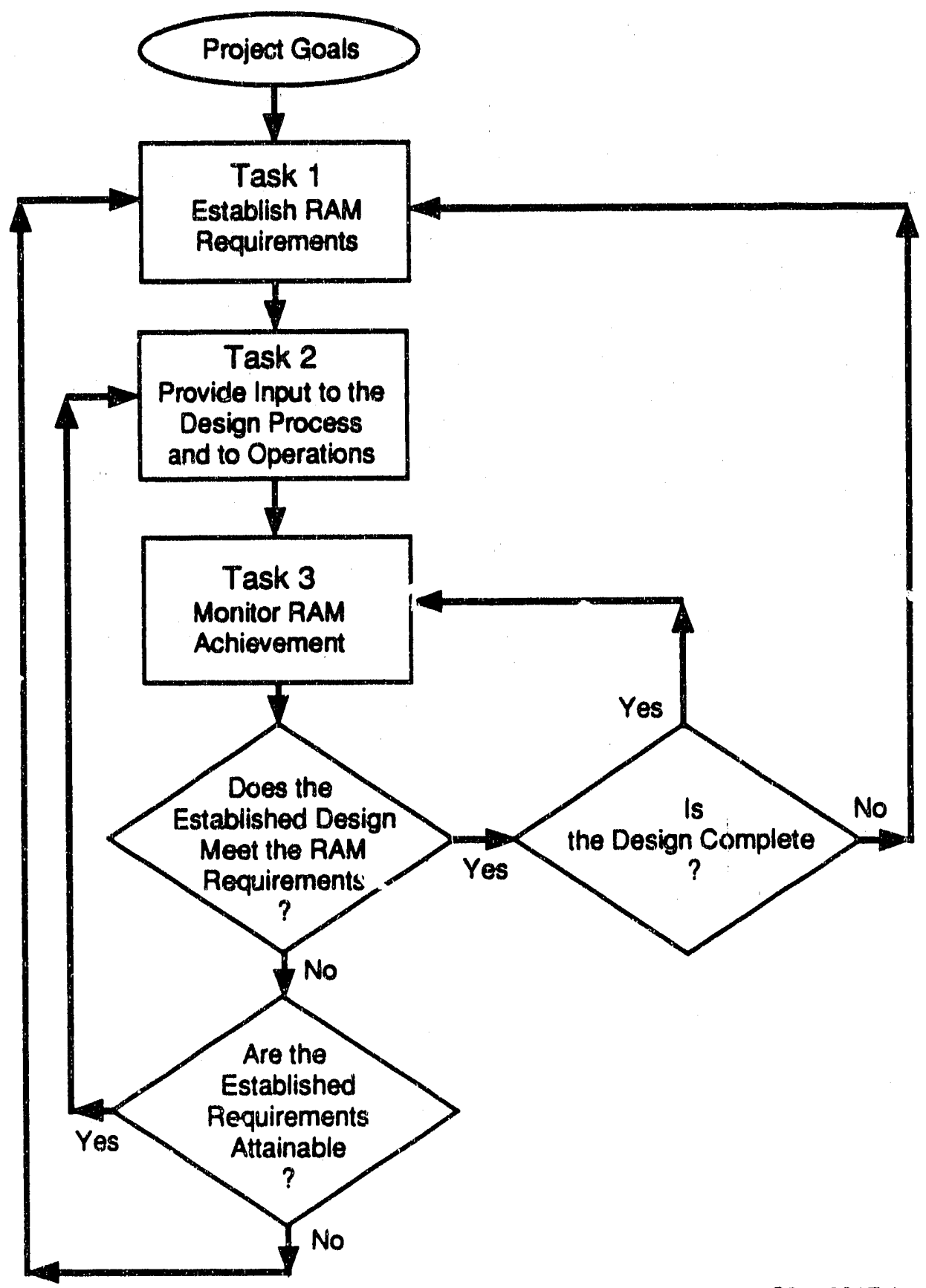

S9110017.1

FIGURE 2.1. Simplified Flowchart of the RAM Process (Guthrie et a1. 1988a) 
- RAM standards for work stations

- RAM standards for individual machines.

- RAM analysis is more general, qualitative, and varied in its application at early phases of major systems development projects than at later design stages, when formal RAM analyses are regularly performed on specific subsystems, plant components, work stations, and machines.

- RAM analysis is appropriate only to the level of detail for which adequate supporting data is available. RAM analysis should be performed in conjunction with system component design as work proceeds, in an iterative manner, increasing the detail of the analysis as more specific and accurate RAM data is made available for components that interact within the system.

\subsection{RECOMMENDATIONS}

Based on the findings of the literature search, facility survey, and RAM analysis, PNL offers the following recommendations:

- System-1evel RAM standards and analyses are recommended as appropriate aids in designing the waste management system. They can be valuable early in the system definition and design processes as long as they accurately reflect the state of knowledge about the system.

- Fundamental system performance objectives (e.g., the most basic schedules, waste priority/acceptance criteria, throughput, dose limits, cost targets) should be established before system-level RAM standards are written. However, system-level RAM-type analysis can be a valuable tool when applied early to help establish practical system performance objectives.

- System-level RAM standards should be few and concisely stated. For each major system element (e.g., individual facilities), an overall availability standard should be set. More detailed RAM analys is can then be used to help design smaller system components in con. formance with system-level standards.

- Detailed RAM analysis for the waste management system is not immediately necessary in view of ongoing work to further define the basic system configuration and performance objectives. Detailed RAM analysis should proceed in an iterative manner in conjunction with system design through increasing levels of specificity. 
- DOE does not need to develop generic RAM tools and guidance materials. Ample resources (instructional materials, computer programs, analytical services) are available. RAM models tailored to the waste management system should be developed from the avallable generic tools. 


\subsection{LITERATURE SEARCH}

For many years, U.S. and international organizations involved in nuclear waste management have studied RAM requirements for sma11- and medium-scale facilities. The literature search and review conducted for this study focused on 1) identifying appropriate principles for developing RAM standards and RAM computational models, 2) identifying and locating essential RAM data, and 3) identifying operating facilities with experience in RAM requirements, RAM testing, or other relevant topics. Both domestic and international data sources were searched, including databases at DOE, the U.S. Nuclear Regulatory Commission (NRC), national laboratories, the U.S. utilities, foreign government sources [foreign equivalents of DOE, the U.S. Environmental Protection Agency (EPA), and foreign national power authorities], and international organizations, such as the International Atomic Energy Agency (IAEA) and the Organization for Economic Cooperation and Development (OECD).

\subsection{RAM GUIDELINES AND RAM ANALYSIS TOOLS}

Guidelines and instructions for performing RAM analyses can be found in textbooks on the relevant basic techniques and, for project-specific applications, basic RAM guidance reports written for DOE's nuclear waste management program (Orvis et a1. 1981). Sufficient instructional and tutorial material is readily available within the existing collection of RAM guidance materials for DOE and its contractors to execute any desired RAM analysis of the OCRWM system.

The literature search located numerous system modeling and/or analytical tools, commercial and proprietary software, and RAM analysis services that apply to the OCRWM system and its components. The offerings include generic industrial modeling, RAM analysis programs, and analytical programs specifically designed for use with particular systems. Examples of generic tools include GPSS (Minuteman Software) (Schriber 1974), QRISK (Palisade Corp.) (Palisade 1988), SIMAN (Systems Modeling Corporation) (Pegden 1985), and RAM analysis service offered by Ralph M. Parsons Company. Examples of systemspecific programs include RAMSIM/NWSI (Sovers 1987) and FACSIM/MRS-2 (Huber et 
a1. 1987) at PNL for the OCRWM system; proprietary models developed by Ralph M. Parsons Company for various systems (RMP 1982, 1985, 1987a, 1989); and two proprietary models of the MITRE Corporation for the U.S. Army's Chemical Stockpile Disposal Program (Goldfarb 1987; Rod and Klingener 1989).

\subsection{RAM DATA}

Reliability data for smal1 machines and machine components (used to support RAM calculations of sma11, relatively simple systems) were abundant in both domestic and international databases; however, reliability data on larger system components (needed to support RAM analysis or to form the basis for RAM requirements for large, complex systems) were almost totally unavailable. The notable exception was data on nuclear power plants as part of the Nuclear Plant Reliability Data System (NPRDS) (SWI 1980).

\subsection{RAM EXPERIENCE}

The 1 iterature search revealed innumerable examples of RAM analyses that had been performed on small elements of systems (e.g., individual machines and work stations) and several examples of factory-scale and facility-level RAM analyses, but no examples of formal, quantitative RAM analyses or standards applied to multiple-facility systems. 


\subsection{SURVEY OF ORGANIZATIONS AND FACILITIES}

The purposes of the facility survey were to 1) identify nuclear waste handling facilities that have incorporated RAM standards into their design and operation (as well as those that have not), 2) identify and collect RAM data found (by field experience) necessary to characterize and support developing and implementing RAM standards, and 3) assess how RAM standards can help large-scale radioactive waste management facilities meet their performance objectives, as revealed by published data and field experience.

A national nuclear waste management system includes waste sources (e.g., numerous commercial nuclear power plants, research and test reactors, government-owned reactor facilities, and other nuclear material production facilities), interim fuel storage facilities, waste processing/packaging facilities, a transportation system, possibly an interim waste storage facility [e.g., monitored retrievable storage (MRS) facility], and at least one permanent waste disposal facility. Several of these system elements have been developed and are operating. For example, the system in France, which consists of fuel reprocessing, waste packaging, interim high-level radioactive waste (HLW) storage, and an internationally licensed transportation system, has been operating for several years. Great Britain, Germany, Sweden, the Netherlands, and Japan, among others, have some portion of a nuclear waste management system either operational or under field-scale study.

Based on the literature search, follow-up contacts were made at major nuclear waste management facilities and architecture and engineering (A\&E) companies with n.clear experience. Table 4.1 shows the principal sources of

relevant RAM data and/or design standards. Interviews and requests for data and reports were conducted by letter or telephone or through arranged site visits. All necessary concurrences, approvals, and clearances were obtained from the appropriate authorities before contact was made in each case. 
TABLE 4.1. Sources of RAM Information (a)

\begin{tabular}{|c|c|c|c|c|}
\hline $\begin{array}{l}\text { System } \\
\text { Element }\end{array}$ & $\begin{array}{c}\text { U.S. } \\
\text { Commercial } \\
\text { Sources } \\
\end{array}$ & $\begin{array}{l}\text { U.S. } \\
\text { Gov./Defense } \\
\text { Sources } \\
\end{array}$ & $\begin{array}{l}\begin{array}{c}\text { Foreign } \\
\text { Commercial } \\
\text { Sources }\end{array} \\
\end{array}$ & $\begin{array}{c}\text { Foreign } \\
\text { Government } \\
\text { Sources } \\
\end{array}$ \\
\hline Reactors & Contacted & Contacted & -- & Contacted \\
\hline Transportation & -- & Contacted & -. & - \\
\hline MRS & Contacted & -- & Contacted & -- \\
\hline $\begin{array}{l}\text { Reprocessing/ } \\
\text { Consolidation/ } \\
\text { Packaging }\end{array}$ & Contacted & - & Contacted & -- \\
\hline Disposal site & -. & Contacted & $\cdots$ & Contacted \\
\hline Regulation & - & Contacted & - & -- \\
\hline $\begin{array}{l}\text { Design/ } \\
\text { Construction }\end{array}$ & Contacted & -- & Contacted & -. \\
\hline
\end{tabular}

(a) See Appendix A, Section A.2 for additional sources.

\subsection{COGEMA INC. AND NUMATEC INC.}

COGEMA is a private industrial company that is wholly owned by the Commissariat a 1'Energie Atomique (CEA), the French Atomic Energy Commission. Its purpose is to provide comprehensive nuclear fuel processing services from uranium mining to permanent waste disposal. NUMATEC, a subsidiary of COGEMA, provides engineering support to the parent company. COGEMA and NUMATEC representatives discussed RAM issues and approaches with regard to two key elements in their nuclear fuel processing system: the spent fuel reprocessing facilities at La Hague and Marcoule and a planned deep geologic repository for HLW.

\subsubsection{French Spent Nuclear Fuel Reprocessing}

Construction of the first French industrial reprocessing facility for irradiated nuclear fuel, the UP 1 plant, began in 1955 at Marcoule, and active operation began in 1958. Basic data for UP 1 design and construction were provided by a pilot plant that had been operating since 1954. There is no recollection of formal RAM analyses being conducted or RAM standards being set for 
the UP 1 plant at Marcoule during design and construction; however, RAM data have been collected continuously on UP ${ }_{1}$ (Delange 1987; Regnault et al. 1989) and have been used in designing the subsequent $U P_{2}$ and $U P_{3}$ reprocessing $p 1$ ants at La Hague. The UP ${ }_{2} \mathrm{plant}$ at La Hague opened in 1976 to reprocess lightwater reactor (LWR) fuel, while UP 3 started operating in 1990. Reliability, availability, and maintainability data collection and feedback to system and equipment performance improvements continues (Bern and Chabert 1989; Dreyfus and Le Blaye 1989).

No quantitative system-1evel RAM analys is was performed before operations began at $U P_{2}$ and $U P_{3}$ at La Hague. RAM-type analyses were performed on the piants' major operations, components, and machines as part of the design phase to identify critical processing paths and redundance needs; but specific, quantitative RAM standards were not established for the reprocessing systems or their components. Instead, COGEMA set broad standards in terms of "guaranteed production capacity" [metric tons of uranium (MTU) processed during a campaign of fixed duration], target "individual dose rates," and general requirements such as "high equipment reliability" (Hutchison and Lemaistre 1987; Bastien-Thiry and Justin 1988). Studies were conducted to maximize utilization and throughput of facilities and minimize plant size. Plants were designed to meet overall performance objectives, but detailed RAM standards were absent.

Once plants opened, improvements in reliability, availability, and maintainability were made through a three phase operation/observation/feedback approach: 1) demonstration of process feasibility, 2) progressive increase in throughput, and 3) operation at nominal capacity. The following schedule for $U_{2}$ at La Hague provides an example (COGEMA 1990):

Operation begins

Demonstration of process feasibility

Progressive increase in throughput

Operation at nominal capacity
1976

$1976-1978$

1979-1983

1983-present. 
For the UP ${ }_{3}$ plant, maintainability of plant components was considered in the plant's conceptual design. NUMATEC performed analyses to minimize the "mean time to replace" components and settled on a broad design philosophy of modular operating units that would be used for a predetermined time and replaced before they falled. Once this scheduled replacement approach was implemented, data on the modules and plant maintainability were complled. Recently, after eight years of data collection, various analyses of the maintenance policy were conducted, and the existing replace-and-dispose procedure is now being replaced with off-line rehabilitation and recycling of used plant modules.

\subsubsection{French Nuclear Waste Disposal}

CEA plans to dispose of HLW by deep burial. COGEMA and NUMATEC are developing conceptual designs for a deep geologic repository, and system-1evel RAM studies are being done as part of the process. A study currently under way at NUMATEC involves investigating the effects of fatlures of critical repository components on the entire nuclear fuel processing system. This critical component analysis will be used in preparing a more detatled design. The study is not publicly available, but the following scenario was cited by NUMATEC as an example of the type of results obtained.

A critical component in the current conceptual design of the deep geologic repository is an elevator platform for lowering waste canisters to the emplacement area. A catastrophic failure of the elevator could result in the entire repository being unavailable for as long as three to four years (the estimated time required for complete replacement of the elevator system). The consequences of repository unavailability then propagate back though the fue? cycle. This result will be considered in subsequent, more detailed design stages.

\subsection{U.S. DEPARTMENT OF ENERGY}

Handling HLW and spent fuel in the U.S. comes under the authority of the DOE. With in DOE are a number of organizations that have specific goals and 
duties related to nuclear materials production and waste. The research is frequently performed by numerous private companies across the country under contract to DOE.

\subsubsection{The U.S. Nuclear Waste Management System}

As discussed in Section 1.0, OCRWM is responsible for develaping a system for managing HLW and spent fuel in accordance with the 1982 NWPA and its amendments. Before enactment of NWPA, OCRWM had explored the use of RAM standards and analyses to help coordinate the development of system elements and to ensure the achievement of overall system performance objectives. A brief 1 ist of some key DOE and DOE-sponsored activities aimed at providing guidance for RAM analysis in the context of the waste management system follows:

1980: Development of a methodology to aid in preparing engineering design criteria for a nuclear waste repository. This investigation included developing a conceptual design for the repository and a preliminary flow diagram for repository equipment and processes

1981: Publication of guidance for performing RAM analyses on repository equipment (Orvis et a1. 1981)

1983-1988: Publication of a series of DOE orders pertaining generally to various aspects of large system development, including consideration of the use of RAM standards and analyses

1988: Publication of additional RAM guidelines (Guthrie et al. $1988 a, b)$.

Other DOE-sponsored activities have investigated specific RAM characteristics of the waste management system and its components (Eger and Zima 1979; Westick et al. 1979; Orvis et a1. 1981; Sovers 1987, 1988; Clark and Myers 1989).

\subsection{WEST VALLEY NUCLEAR SERVICES CORPORATION}

In 1980 Congress passed the West Valley Demonstration Project Act, which directed DOE to conduct a HLW solidification demonstration at the Western New York Nuclear Service Center. Large volumes of liquid HLW are currentiy stored 
in tanks from a former commerctal nuclear fuel processing plant that operated at West Valley from 1966 to 1972. Under the terms of the Act, West Valley is to:

- solidify the HLW into a form suitable for transport and disposal

- develop suitable containers for the permanent disposal of the solidifled waste

- transport the solidified waste to a federal repository for permanent disposal as soon as is feasible

- dispose of the low-level waste (LLW) and transuranic wastes it produces

- decontaminate and decommission the facility, equipment, and materials used in HLW solidification.

West Valley Nuclear Services Corporation (WVNSC), a subsidiary of the Westinghouse Electric Corporation, is designing the system to solidify (vitrify) the HLW at West Valley. The literature search found numerous technical reports on various aspects of the design of the vitrification system and its components, but none of the design reports dealt with RAM analysis.

Follow-up interviews with the WVNSC engineering staff revealed that there had been no formal RAM analysis performed as part of developing the vitrification process, nor had establishing RAM standards been considered. However, consideration was given to reliability and availability issues, which were investigated on an ad hoc basis as needed for specific features of the system.

To improve system and equipment avallability, WVNSC has relied more on feedback from actual equipment tests and monitoring of system performance. For example, when recent tests of the waste glass meiter system were completed, it was stated that "these tests confirmed equipment operability, control system reliability, and provided samples of waste glass for durability testing" (WVNSC 1989).

The vitrification system description is not yet complete. The current major focus of analytical activity in WVNSC's system Engineering and Support: Department is preparing the preliminary safety analysis report. Certatn 
features of RAM analysis will likely be included in probabilistic risk assessments and fallure mode analyses that will be performed as part of the overal1 safety analysis effort, but formal RAM analysis is not contemplated at this time.

A system-level RAM analysts, Eailure Modes and Effects Analysts of the West Valley Nuclear Services Vitrification System (Westick et a1. 1979), was performed in 1987 by PNL. The abstract of that report states:
"A fallure modes and effects analysis. (FMEA) was performed to identify design changes and other corrective actions to improve system integrity and operational performance of the West Valley Demonstration Project vitrification system. The FMEA includes descriptions of the failure modes and causes of those fatlures, possib?e effects of the failures, qualitative estimates of the probability and severity of the failures, and possible corrective actiors. Nineteen items were identified as having a high failure frequency or a medium failure frequency with lengthy repair times. An additional thirty items were identified whose fallures could be mitigated or eliminated by design modifications or additional moni- toring. Recommendations for improving these items are provided. An effort was also made to quantify the failure rates and repair times to prioritize the important components and to estimate the vitrifteation system's availability."

\subsection{GENERAL ELECTRIC CORPORATION MORRIS OPERATION}

General Electric's (GE) Morris Operation is an independent spent fuel storage installation (ISFSI) near Morris, Illinois, adjacent to the Dresden Nuclear Power Station. It has spent fuel pools with a total 1icensed capacity of 750 MTU (GE 1990). It has been operating with this capacity since 1976 and has in recent years been operating virtually in a steady-state, storage-only mode, since spent fuel shipments have been curtalled. The facility's operations and maintenance programs are probably typical of those that would be encountered at future wet-storage ISFSIs.

At the time Morris was designed and built, RAM standards were not considered critical to ensuring successful plant operations, and RAM considerations are not included in Morris Operation's consolidated Safety Analysis Report (GE 1990). Due to external constraints, the schedule of operations at 
Morris currently has considerable exress capacity and RAM standards are, for all practical purposes, moot.

In 1979 the NRC commisstoned a study of spent fuel storage operations at the Morris Operation (Eger and Zima 1979). The study was to provide a description of spent fuel handling activities and systems and to analyze the system's performance over its (then) seven-year operational history. Although the analysis focused not on throughput but on safety-related performance measures (e.g., containing radioactive materials, shielding against radiation, preventing criticality), it did have RAM implications.

\subsection{U.S. NUCLEAR REGULATORY COMMISSION}

An extensive literature search of NRC reports revealed very little in the way of RAM studies, RAM guidance, or the promulgation of RAM standards in regulations or orders. The few examples of RAM requirements set by the NRC derive from safety standards (Tzanos and Bezella 1984). The NRC does participate in the collection of RAM data for use within the nuclear industry; for example, it publishes NUREG reports containing nuclear-specific RAM data from the Nuclear Plant Reliability Data System (NPRDS), a source of reliability and failure information on safety-related systems and components (SWI 1980). The NRC also contracted a retrospective RAM-type study of the Morris Operation's spent fuel storage facility as part of its oversight responsibility with respect to ISFSIs (Eger and Zima 1979).

The NRC performs (or contracts to have performed) RAM analyses where they are required to address specific nuclear safety issues. For instance, in the investigation of Generic (safety) Issue 99, "Loss of Residual Heat Removal (RHR) Capability in PWRs," the NRC performed a RAM analys is and set RAM standards to ensure that the RHR systern could be relied upon to provide backup reactor cooling in certain emergency situations (Tzanos and Bezella 1984; Chu et a1. 1988; Spano 1989).

\subsection{NUCLEAR INOUSTRY ORGANIZATIONS}

Nuclear plant and equipment reliability, availability, and maintainability has been an ongoing issue for the industry, motivated by both economic 
and safety considerations. However, there is apparently litt?e work by indus try on RAM issues for large-scale systems. Several organizations sponsored by the nuclear industry conduct generic research for the benefit of the industry as a whole (e.g., the Electric Power Research Institute [EPRI], the Edison Electric Institute, the Institute for Nuclear Power Operations, and the Nuclear Safety Analysis Center). However, their studies typicaliy focus more on specific, high-visibility issues or current problems, intending to maintain or improve nuclear plant performance at existing facilities. While various generic industry studies include some RAM-type information or RAM-type analysis, formal RAM analysis at the system level has not been emphasized. Other analysts (those closer to specific facilities, systems, and equipment design tasks) more frequently perform RAM analyses as they need them.

Though nuclear industry organizations have not emphasized establishing RAM standards or performing RAM analyses themselves, they have organized systems to compile, store, and disseminate RAM data for the benefit of other RAM analysts. The NPRDS, sponsored by the American Public Power Association, the Edison Electric Institute, the Tennessee Vallev Authority, and the NRC, is an example of a nuclear-specific database of RAM information and experience. The NPRDS was designed to "serve as a source of reliability and failure information for operators, designers, manufacturers, architect-engineers, constructors, and regulators of safety-related systems and components" (SWI 1980). Its primary purposes are "to provide operating statistics of safety-related systems within a unit which may be used to compare and evaluate reliability performance and to provide failure mode and failure rate statistics on components to be used in failure mode effects analysis, fault hazard analysis, and probabilistic reliability analysis" (SWI 1980).

The nature of the nuclear industry's efforts in the RAM field can be summarized as being "descriptive" rather than "prescriptive," that is, they describe the RAM parameters of system components and are used to maximize system availability from the bottom up. They are not yet being used to set RAM requirements for lower-level system components to meet a preset overall system RAM standard. 


\subsection{WESTINGHOUSE ELECTRIC CORPORATION}

Westinghouse is a major worldwide vendor of nuclear steam supply systems (NSSS), as well as a provider of advanced analysis services for a great variety of clients. Virtually all of their analytical work in the area of systems analysis [e.g., RAM analysis, failure mode analysis, probabilistic risk assessment (PRA), and human factors analysis] are for private clients. The two main thrusts of the company's work in this area are related to improving nuclear plant efficiency (i.e., profitability) and safety (driven by both business and regulatory imperatives).

Westinghouse regularly performs RAM analyses on sma11- and medium-scale systems such as specific safety systems at nuclear power plants. To the extent that power $\mathrm{plant}$ systems interact in complex ways, such system interactions are frequently incorporated into the analyses. PRAs corcentrate on failure modes of safety systems and their consequences and are used more often than RAM analyses for large-scale systems (e.g., an entire nuclear power plant).

RAM standards have not been used as part of fundamental nuclear plant design criteria. No mention is made of formal RAM analysis or standards in plant design or plant licensing guidelines. RAM analysis is not included in Westinghouse's basic plant licensing report, the Reference Safety Aralysis Report (RESAR) (Westinghouse 1975). RESARs are submitted to the NRC in accordance with 10 CFR 50, "Standardization of Design Staff Review of Standard Designs." Westinghouse first issued a RESAR in 1970 as part of its efforts toward design and licensing standardization of its NSSS.

\subsection{MITRE CORPORATION}

The MITRE Corporation was contracted to assist the U.S. Army destroy its stockpile of obsolete chemical agents and munitions. MITRE has participated in various aspects of the program, including facility and process conceptual design, performance testing and analysis, system modelir.y, and RAM analysis. Most of the program's reports, including those relevant to RAM standards and analyses, are not approved for public release; however, MITRE representatives agreed to discuss their RAM studies. 


\subsubsection{The U.S. Army Chemical Stockpile Disposal Program (CSDP)}

The chemical stockpiles at eight Army storage facilities are to be destroyed. In each case the entire process will be conducted on the base; no offsite transportation of chemical munitions is planned. The munitions will be removed from their concrete storage "igloos," loaded into transport containers, transported onsite, unloaded into a container handling building (CHB) for temporary storage and possible thawing, and moved to the adjacent main demilitarization building (MDB) for disassembly and incineration. Figure 4.1 shows the basic process (Rod and Klingener 1989).

Two facilities have already been built to demonstrate the destruction process. The first operating facility, the Chemical Agent Munitions Disposal System (CAMDS), is a pilot piant in Tooele, Utah, used to test various processes and gather operational data, including large amounts of RAM data. The Johnston Atoll Chemical Agent Disposal System (JACADS) is a full-scale processing facility that is presently gearing up to demonstrate the complete destruction process as it will be carried out at the eight future chemical weapons destruction facilities.

MITRE has performed numerous RAM analyses on the CAMDS and JACADS facilities and sub-elements of these facilities, including individual machines (Wusterbarth et a1. 1988, 1989, 1990). The results of RAM analyses at each stage of program development were used as input into subsequent development and design stages. RAM data collected at CAMDS, along with RAM analyses of early JACADS designs, were used to refine the final JACADS design. JACADS RAM data and additional conceptual MDB RAM analyses are being used to refine MDB designs.

The RAM analyses performed as part of the chemical stockpile disposal program (CSDP) describe the RAM parameters of system components and are used to maximize system availability from the bottom up. They are not yet being used to set RAM requirements for lower-level system components to meet a preset overall system RAM standard.

The only system-level studies that resemble RAM-type studies performed to date on the CSDP system are a "logistical analysis in support of 


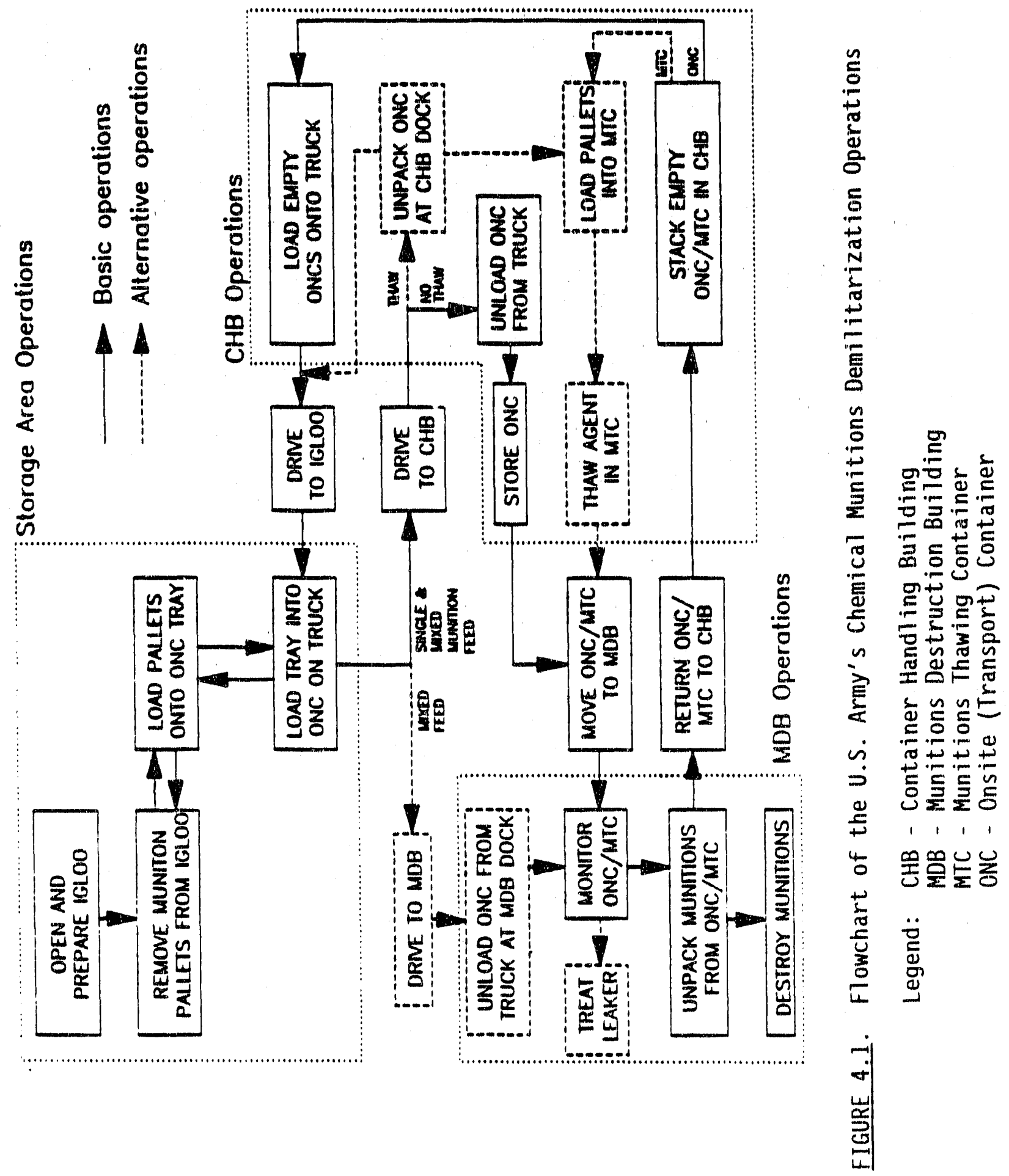


demilitarization operations" (Rod and Klingener 1989) and a similar follow-on study currently under way at Ralph M. Parsons Company. These studies assess the performance of the conceptual system shown in Figure 4.1 under vartous logistical assumptions and adverse external conditions. They are being used to determine building and buffer sizes and equipment requirements.

MITRE has recommended to the Army that a comprehensive formal RAM analysis be performed for the conceptual onsite demilitarization system; the Army is agreeable to conducting such an analysis while the eight onsite facilities are still in the early design stages.

\subsection{RALPH M. PARSONS COMPANY}

The Ralph M. Parsons Company provides a wide range of engineering, architectural, and project management services to government and private industry. Its services include systems analys is work such as RAM analysis, PRA, and risk/benefit analys is (RMP 1990b).

Confidentiality constraints prevented Parsons representatives from discussing or releasing details of specific clients' applications of system-level RAM analysis. They did, however, describe Parsons' typical use of RAM standards and analyses.

Parsons routinely performs formal RAM analysis for engineered systems at many leveis of complexity: machines, work cells, major components or operations within facilities, and entire industrial facilities. RAM analyses of multiple-facility systems are rare, mainly because such systems are rather rare. One example of a system-level quasi-RAM study, the U.S. Army's chemical stockpile disposal program (CSDP) is cited below.

System-level RAM analyses (whole-factory RAM analyses) would typically be conducted as an integral and ongoing part of the following facility design process:

- Fundamental objectives are developed in consultation with the client. Fundamental objectives may include schedule, throughput, cost, and safety goals.

- "Availability goals" for the overall system are derived from the mission objectives. 
- Preliminary system designs ("0\% designs" - functional block diagrams, equipment general arrangement, etc.) are created, based on mission goals.

- Various system performance analyses are performed, possibly tncluding elements of RAM analysis, at a level of detail consistent with the extent of facility design and the availability of RAM data.

- More detailed design is undertaken, incorporating the results of the previous system analyses and numerous other inputs, both quantitative and qualitative.

- Formal RAM analysis is typically performed, incorporating the additional information developed during the design process at about $35 \%$ design completion. Results of the analysis are compared with availability goals, and modifications to the system may result.

- Formal RAM analysis is again performed at about $90 \%$ completion, incorporating the new design data. Results of the analysis are compared with availability goals.

- A final system design will be created based on these analyses, other analyses, and various other considerations.

This general approach has been applied to several projects, including the Strategic Petroleum Reserve, other oil and gas facilities (RMP 1990b), Idaho National Engineering Laboratory's (INEL) Remote Analytical Laboratory (RMP 1982), INEL's Fuel Processing Restoration Facility (RMP 1985, 1987b), the U.S. Army's Multiple Launch Rocket System Binary Chemical Warhead Production Facility (RMP 1989), and the Army's CSDP in a study done by Ralph M. Parsoris Company in 1990. RAM analys is was not used and no RAM requirements were considered when Parsons developed a preconceptual design for an MRS transfer facility within the U.S. nuclear waste management system (RMP 1990a; Wood et a). 1991).

\subsubsection{The U.S. Army Chemical Stockpile Disposal Program (CSDP)}

Like MITRE, Parsons has been contracted to assist the U.S. Army in destroying its stockpile of obsolete chemical agents and munitions. Parsons has been involved in various aspects of the program, including both conceptual and detailed design of facilities, system modeling, and RAM analysis. None of the existing Parsons reports on the program, including those relevant to RAM stan- 
dards and analyses, are approved for public release; however, Parsons representatives discussed their RAM studies for the CSDP.

Parsons performed numerous formal RAM analyses on the CAMDS and JACADS facilities (RMP 1987a). The results at each stage of program development were used as input into subsequent development and design stages. However, 1ike the MITRE studies previously discussed, Parsons' reports are descriptive. They are not yet being used to set RAM requirements for lower-level system components to meet a preset overall system RAM standard.

The only system-level studies that resemble RAM-type studies performed to-date on the CSDP system are mare detatled follow-up studies to the MITRE logistical analysis (Rod and Klingener 1989). These studies are being used to determine building sizes, buffer sizes, equipment requirements, and other design criteria.

\subsection{BECHTEL GROUP INCORPORATED}

Bechtel provides a wide range of services to both government and private clients, including virtually all industrial sectors. Under the broad heading of "Systems Engineering," the company provides services covering all phases in developing major industrial projects, including RAM analysis, system analysis, PRA, and risk/benefit analysis. Bechtel conducts its system engineering activities through three major business 1 ines: "Power, "Refinery and Chiemical," and "Manufacturing."

For reasons of confidentiality, Bechtel provided no documentation describing the company's experience with or applications of system-level RAM analysis. However, PNL received approval from Bechtel's president to interview the manager of Engineering Technology, Special Operations, Bechtel Group. A summary of the interview follows.

\subsubsection{Power, Refinery, and Manufacturing Systems}

Analyses are always conducted at the earliest stages of major engineering projects (e.g., power plants, refineries, factories) to identify critical aspects of the system under design and ensure that it meets the client's 
objectives. This analysis may or may not be called RAM analysis, but features of RAM-type analysis are part of the system analysis.

The initial system analysis is tallored to the characteristics of the particular system under development. For electric power plants, system reliability, availability, and maintainability are affected by complex interactions among many plant systems. Therefore, Bechtel performs "interactions analysis" to understand how component or system failures propagate to shut down the power station (as plant designs progress, this type of analysis evolves into formal PRA). Refineries and chemical processing plants are characterized by the throughput of bulk materials. For these types of facilities, input/ output analysis is performed to identify critical nodes (or choke points) and the consequent need for buffers or queues in the process path. For manufacturing plants, the need for efficient parts delivery and inventory management systems calls for "just-in-time" studies, which are an extension of input/ output analyses.

For all industrial design and development projects, Bechtel's aim is to determine (and optimize) the resilience of the system (how rapidly backup processes and/or procedures can restart the system after a failure). Also, in the early stages of all projects, system-level RAM-type standards are derived from the client's preliminary objectives (e.g., throughput, cost, productivity, and safety goals). Early standards are frequentiy stated qualitatively and are made more quantitative through several iterations of system analysis and facility design. As system design progresses, more specific RAM standards are determined by the higher-level requirements (i.e., system requirements determine facility requirements, which determine work station requirements, which determine machine requirements, etc.). The development process, however, remains a mixture of quantitative analysis and heuristic design improvements. 


\subsection{SYSTEM LEVEL RAM MODEL AND ANALYSIS OF THE U.S. NUCLEAR WASTE MANAGEMENT SYSTEM}

PNL created a system-level RAM computational model using the existing commercial software SIMAN to perform the system-level RAM analysis for the U.S. waste management system (Pegden 1985). Its purpose was to explore the usefulness of RAM analysis for gaining insights into the operational relationships among major waste system facilities.

For this initial exploration, the model was kept as simple as possible, including only a "Level 0 " description of the basic system as described in System Description of the Basic MRS System for the FY 1990 Systems Integration Program Studies (Mckee et a1. 1991). The RAM model includes six major elements: waste generators, waste-generator-to-MRS transportation, wastegenerator-to-repository transportation, the MRS, MRS-to-repository transportation, and the repository.

The analysis yielded results consistent with those of earlier RAM studies of alternative system configurations (e.g., MRS, multiple MRS, and repository-oniy systems). Though the analysis at the level of detail used in this study produced rather straightforward results, it is clear that systemlevel RAM analysis can yield valuable insights on the kinds of issues that are critical to the waste management program (e.g., queue and interim storage sizes, average and peak inventories).

Sample results of the calculations performed for this study are presented in Appendix B. 


\subsection{REFERENCES}

10 CFR 50. 1990. U.S. Nuclear Regulatory Commission. "Standardization of Design Staff Review of Standard Designs." Code of Federal Regulations.

Bastien-Thiry, H., and F. Justin. October 1988. "Safety Engineering Achievements in Handling Casks at La Hague." Nuclear Europe, 8(10):25-26.

Bern, J. B., and J. Chabert. September 1989. "Diagnostic Aid and Maintenance at the La Hague Reprocessing Plants." Operabllity of Nuclear Systems in Normal and Adverse Environments, Volume 2. Societe Francalse d'Energle Nucleaire, Parts.

Chu, T-L., R. Fitzpatrick, W. H. Yoon, and A. Tingle. 1988. Improved Reliability of Residual Heat Removal Capability in PWRs as Related to Resolution of Generic Is sue 99. NUREG/CR-5015 (BNL-NUREG-52121), Brookhaven National Laboratory, Upton, New York.

Clark, L. L., and R. S. Myers. 1989. MRS Systems Study Task I Report, Waste Management System Reliability Analysis. PNL-6875, Pacific Northwest Laboratory, Richland, Washington.

COGEMA, Inc. 1990. The Nuclear Fuel Cycle Back End - A Cogema Vtew. nd. RCS 312381895, Monkey Press, Paris.

Delange, M. November 1987. "Reprocessing of Fuels from Light-Water Reactors. Performance Evolution of the La Hague Plant." Review of Energy, $38(397): 569-575$.

Dreyfus, G. P., and G. Le Blaye. September 1989. "Qualification of Technical Equipment for the New UP. Reprocessing Plant at La Hague." Operability of Nuclear Systems in Normal and Adverse Environments, Vol. 2. Soctete Francaise d'Energie Nucleaire, Paris.

Eger, K. J., and G. E. Zima. 1979. Commentary on Spent Fuel Storage at Morris Operation. NUREG/CR-0956 (PNL-3065), U.S. Nuclear Regulatory Commission, Washington, D.C.

General Electric Corporation (GE). 1990. Consolidated Safety Analys is Report for Morrts Operation. NEDO-21326D4, USNRC Docket \#70-1308, Morris, I11 inois.

Goldfarb, A. S. 1987. "A Simulation of a Process for Destroying the Army Stockpile of Obsolete Chemical Munitions." Proceedings of the 18th Annual Modeling and Simulation Conference, Vol. 18, pp. 399-406. April 23-24, 1987, University of Pittsburgh Press, Pittsburgh, Pennyslvania.

Guthrie, V. H., J. A. Farquharson, and D. J. Campbe11. 1988a. Reliability, Availability, and Maintainability (RAM) Guidelines. JBFA-102R-88, JBF Associates, Inc., Knoxville, Tennessee. 
Guthrie, V. H., J. A. Farquharson, and H. M. Paula. 1988b. RAM Application study for the Proposed Waste Manaciement Systen, JBFA-LR-104-88, JBF Assoclates, Inc., Knoxyllle, Tennessee.

Huber, H. D., A. D. Chockte, C. J. Hostlck, P. T. Otts, and R. A. Sovers, 1987. FACSIM/MRS-2: Storage and Shipping Model Documentation and User's Guide. PNL-6003, Pacific Northwest Laboratory, Richland, Washington.

Hutchison, C., and P. Lemaistre. 1987. "Large-Scale Spent-Fuel Cask Reception and Dry Unloading at La Hague." Iransactions of the American Nuclear Soctety, Vo1. 54, pp. 60-61.

Mckee, R. W., J.R. Young, and G. J. Konzek. 1991. System Descriptiton of the Bastc MRS System for the FY 1990 Systems Integrat on Program Stud tos. PNL-7508, Pacific Northwest Laboratory, Richland, Washington.

Orvis, D. D., M. V. Frank, F. K. Jacobsen, and W. M. Clarke. 1981. Guidebook for Reliabllity. Avallabllity, and Maintainabllity Analys is of NWTS Repos itory Equipment, Vol. I and II. ONWI-334, Office of Nuclear Waste I solation, Battelle Memorial Institute, Columbus, Ohto.

Palis ade Corporation. 1988. QRISK. Newfiteld, New York.

Pegden, C. D. 1985. Introduction to SIMAN with Version 3.0 Enhancements. Systems Mocieling Corporation, State College, Pennsylvania.

Ralph M. Parsons Company (RMP). 1982. A Computer Simulation of Analytical Operations in the RAL. 5586-FAST-52, U.S. Department of Energy, Idaho Operations office, Idaho Falls, Idaho.

Ralph M. Parsons Company (RMP). 1985. P\&V Corrldor Avallabllity Revised Analysis for Euel Processing Restoration Project. DOE/ID/12235-41, U.S. Department of Energy, Idaho Operations Office, Idaho Falls, Idaho.

Ralph M. Parsons Company (RMP). 1987a. Avallability Analysis Computer Code Users Manual. DOE/ID-12235-47, U.S. Department of Energy, Idaho Operations Office, Idaho Falls, Idaho.

Ralph M. Parsons Company (RMP), 1987b. Reliabtlity, Availability, Maintainability (RAM) Analys is of Final Destgn per TEAD Tests. Ralph M. Parsons Company, Pasadena, Caltfornia.

Ralph M. Parsons Company (RMP). September 1989. Production Fil1/Close Eactlity - Rellability. Avallability and Maintainability (RAM) Report. Prepared by The Ralph M. Parsons Company for Chemtcal Research, Development and Engineering Center, Aberdeen Proving Ground, Maryland.

Ralph M. Parsons Company (RMP). 1990a. Preconceptual Deston for an MRS Iransfer Facility. PNL-7400, Pacific Northwest Laboratory, Richland, Washington. 
Ralph M. Parsons Company (RMP), 1990b. Capabllittes and Experfence in Safety and Risk Management, Envi ronmental, Safoty, and Health (ES\&H). Ralph M. Parsons Company, Pasadena, Californla.

Regnault. H., D. Alexandre, and P. Saverot. 1989. "Start-Up of Commerclal High-Level Waste Vitriftcation Facllities at La Hague." Iransactions of the Amertcan Nuclear Socjety, Vol.60, p. 168.

Rod, S. R., and F. J. Klingener. March 1989. LoglstJcs Analysts of On.S1te Movement of Munitions for the Chemical Stockptle Disposal Program. WP-88W00453, The MITRE Corporatton, Mclean, Virginta.

Schrlber, T. J. 1974. Simulation Using GPSS. John Wtley and Sons, Now York.

Southwest Research Institute (SWI). September 1980. Nuclear Plant Rellabiltty Data System 1979 Annual Reports of Cumulat ve System and Component Rellability. NUREG/CR-1635, prepared by Southwest Research Institute for the U.S. Nuclear Regulatory Commitsston, Washington, D.C.

Sovers, R. A. 1987. RAMSIM/NWSI - Nuclear Waste System Integration Rel1abjlity, Avallabillty Simulation Model. PNL-5980, Pacific Northwest Laboratory, Rlchland, Washington.

Spano, A. H. 1989. Requlatory Analysts for the Resolution of Generic Is sue 99. "Los of RHR Capabillty in PWRS." NUREG-1340, U.S. Nuclear Regulatory Commisston, Washington, D.C.

Tzanos, C. P., and W. A. Bezella. 1984. Risk Related Relfability Requirements for BWR Safety-Important Systems with Emphas is on the Res Idual Heat Removal System. NUREG/CR-3933, U.S. Nuclear Regulatory Commission, Washington, D.C.

Westick, J. H. Jr., T. V. Vo, F. A. Fraf, Jr., J. M. Perez, Jr., F. H. Fisher. 1979. Fallure Modes and Effects Analysts of the West Valley Nuclear Services Vitrification System. WVST 87/209, West Valley, New York.

Westinghouse Electric Corporation. July 1975. Reference Safety Analys is Beport. RESAR-3S, Pittsburgh, Pennsylvanta.

West Valley Nuclear Services Corporation (WVNSC). 1989. West Valley Demonstration Project, West Valley, New York: Annual Repurt. WVDP-89AR, West Valley, New York. 
Wood, T. W., D. G. Dippold, S. R. Rod, S. M. Short, and J. Williams. Aprtl 1991. "Rethinking the Economics of Centrialized Spent Fuel Storage."

Proceedings of the Second Annual Internai ional High Level Radjoact tve Waste Management Conference and Expositton. Amertcan Soctety of Civil Engtreers, American Nuclear Soctety, and the University of Nevada at Las Vegas. Aprt1 28-May 3, 1991, Las Vegas, Nevada.

Wusterbarth, A. R., D. M. Medville, and J. C. T. Morse. 1989. Rellabllity of the CAMDS Multipurpose Demilitarization Machine with Inert M360 Projectiles. MTR-89W00210, The MITRE Corporation, Mclea.7, Virginta.

Wusterbarth, A. R., D. M. Medvi11e, and J. C. T. Morse. 1990. Maintainability Testing of the CAMOS Mult tourpose Demil ttartzation Machine.

MTR-89W00195, The MITRE Corporation, McLean, Virginia. 


\subsection{BIBLIOGRAPHY}

A:le1, P. S., and D. M. Medville. 1987. Procedures and Methodology for Reliability and Maintainability Testing of Baseline Demilitarization Iechnology Subsystems. WP87W81, The MITRE Corporation, McLean, Virginta.

Anantatmula, R. P. 1984. "Preliminary Reliability Analys is of Container Ltfetime." RHO-BWI-TI--249, Rockwell Hanford Operations, Richland, Washington.

Blinn, K., and H. Queiser. 1988. "Improved Methods for Rarioactive Waste Management at Nuclear Power Plants in the Federal Republic of Germany." Proceedings of an International Conference on Nuclear Power Performance and Safety, Vol. 5, pp. 227-233. IAEA-CN-48/107, International Atomic Energy Agency, Vienna.

Dippold, D. G., and K. L. Basinger. 1990. "Optimal MRS Logistics: An Economic Analysis." OrSP/TM-13, Battelle Memortal Institute, Columbus, Ohto.

Elsden, A. D. 1984. "The Management of Intermediate Level Radioactive Waste Arising from Reprocessing Operations." Progress in Nuclear Energy, $13(1): 19-30$.

Endrenyi, J. 1978. Reliability Modeling in Electric Power Systems. John Wiley \& Sons, New York.

Fanning, D. 1988. "Estimated DPE PMD Repair Times from M60 RAM Test." SDSTE-AEC (755-2f), Ammunition Equipment Directorate, Tooele, Utah.

Fanning, D. 1988. "PMD Reliability Test, M60 Projectiles." SDSTE-AEC (7552f), Ammunition Equipment Directorate, Tooele, Utah.

Fanning, D. 1988. "Status of Malfunctions from M60 RAM Test." Briefing to Demflitarization Technology Test Program Systems Management Team Meeting, Apri1 26, 1988. Ammunition Equipment Directorate, Tooele, Utah.

Frost, C. R., S. J. Maqvi, and R. A. McEachran. 1987. "Design Considerations and Operating Experience with West Storage of Ontario Hydro's Irradiated Fue 1." Proceedings of the 1987 International Waste Management Conference, pp. 447-456. American Society of Mechanical Engineers, New York.

Government-Industry Data Exchange (GIDEP). 1989. Reliability-Maintainability (R-M) Analyzed Data Summaries. Reliability-Maintainability Data Interchange, GIDEP Operation Center, Corona, California.

Government-Industry Data Exchange Program (GIDEP). 1990. Index of Reports for December 1990. GIDEP Operation Center, Corona, California. 
Gordon, G. E. 1988. Test Report for the Non-Burstered Projectile Line System (LS). Phase II of the Multipurpose Demil Machine (MDM) Processing 105mm

Simulant-Filled M60 Projectiles. Draft Test Report No. 97-09, CAMDS

Directorate, Tooele Army Depot, Tooele, Utah.

Guais, J-C. 1988. "Closing the Fuel Cycle: An Industrial Demonstration." Proceedings of An International Conference on Nuclear Power Performance and Safety, Vol. 5, pp. 573-579. IAEA-CN-48/96, International Atomic Energy Agency, Vienna.

Homyk, W. A., D. J. Maffei, and M. Kirshe. 1988. "Optimization of PWR Waste Water Treatment: A Case Study - Consolidated Edison - Indian Point II." Waste Management 88, Vo1. 1, pp. 477-482, R. G. Post, ed. American Nuclear Society, University of Arizona, Tucson, Arizona.

The Institute of Electrical and Electronics Engineers (IEEE), Inc. 1987. IEEE Gu,de for General Principles of Reliability Analysis of Nuclear Power Generating Station Protection Systems. IEEE Std. 352-1987, New York.

Joy, D. S. 1989. Documentation and User's Guide - Systems Integration Operations/Logistics Model (SOLMOD) Version 2.1. Oak Ridge National Laboratory, Oak Ridge, Tennessee.

Kingsbury, R. J., et al. 1980. "Methodology to Aid in Preparing Engineering Design Criteria for a Nuclear Waste Repository Equipment and Processes: Task Summary Report for Conceptual Study Review and Functional Flow Diagram Development." Los Alamos Technical Associates, Inc., Los Alamos, New Mexico.

Kuribayashi, H., N. Kurumada, S. Shibata and K. Kugai. 1987. "Improvement of the High Temperature Slagging Incineration System." Proceedings of the 1987 International Waste Management Conference, pp. 203-207. American Society of Mechanical Engineers, New York.

Lakner, A. A., and K. T. Andersun. 1985. Reliability Engineering for Nuclear and Other High Technology Systems. Elsevier Applied Science Publishers, Essex, England.

Leigh, I. W., and M. D. Patridge. 1991. International Nuclear Fuel Cycle Fact Book, Rev. 11. PNL-3594, Pacific Northwest Laboratory, Richland, Washington.

Martin Marietta Energy Systems (MMES), Inc. 1985. AVLIS Reliability, Availability, and Maintainability Program Plan. JID 85-37, Oak Ridge, Tennessee.

McCormick, N. J. 1981. Reliability and Risk Analysis. Academic Press, New York.

Munasinghe, M., and M. Gellerson. 1979. "Economic Criteria for Optimizing Power System Reliability Levels." The Bell Journal of Economics, 10(1):35365. 
National Center of Systems Reliability Data Book, Volume 2. 1979. U.K. Atomic Energy Agency, Warrington, England.

North American Electric Reliability Council (NAERC). 1988. "Generating Availability Data System." Generating Availability Report, 1983-1987. NAERC, Princeton, New Jersey.

OECD/NEA and SKB Swedish Nuclear fuel and Waste Management Company. 1987.

"Nuclear Waste Management - Sweden."

OECD/NEA and Atomic Energy of Canada Limited. 1988a. "Nuclear Waste Management - Canada."

OECD/NEA and COVRA NV Centraie Organisatie Voor Radioactief Afval. 1988b.

"Nuclear Waste Management - The Netherlands."

OECD/NEA and ENRESA Spanish Radioactive Waste Management Company. 1988c.

"Radioactive Waste Management - Spain."

OECD/NEA and U.S. Department of Energy, Office of Civilian Radioactive Waste Management. 1988d. "Managing the Nation's Nuclear Waste."

OECD/NEA. June 1990. "Index of Radioactive Waste Management Computer Programs." Nuclear Waste Bulletin. Nuclear Energy Agency/Organization for Economic Co-operation and Development.

Ouderkirk, S. J. 1988. WASTES-II: Waste System Transportation and Economic Simulation Release 24 User's Guide. PNL-5714, Pacific Northwest Laboratory, Richland, Washington.

Shooman, M. L. 1968. Probabilistic Reliability: An Enqineering Approach. McGraw-Hill Book Company, New York.

U.S. Department of Defense (DOD). 1977. Military Standard: Reliability Growth Testing. MIL-STD-1635(EC), U.S. DOD, Washington, D.C.

U.S. Department of Defense (DOD). 1977. Military Standard: Reliability Design Qualification and Production Acceptance Tests: Exponential Distribution. MIL-STD-781C, U.S. DOD, Washington, D.C.

U.S. Department of Defense (DOD). 1980. Reliability Program for Systems and Equipment Development and Production. MIL-STD-785B, U.S. D0D, Washington, D.C.

U.S. Department of Energy (DOD). 1989. Spent Fuel Storage Requirements 1989 - 2020. DOE/RL-89-30, DOE Field Office, Richland, Washington.

U.S. Department of Energy (DOD). 1990. Spent Fuel Storage Requirements 1990 -2040. DOE/RL-90-44, DOE Field Office, Richland, Washington. 
Verna, B. J., ed. "Nuclear Power Experience." Published bimonthly by Nuclear Power Experience Inc., Encino, California.

Von Alven, W. 1964. Reliability Engineering. Prentice-Ha11, Inc., Englewood Cliffs, New Jersey.

Walling, R. C., C. M. Heeb, and W. L. Purcel1. 1988. Reactor-Specific Spent Fuel Discharge Projections: 1987 to 2020. PNL-6430, Pacific Northwest Laboratory, Richland, Washington. 


\section{APPENDIX A}

MISCELLANEOUS BACKGROUND INFORMATION 
APPENDIX A

MISCELLANEOUS BACKGROUND INFORMATION

\section{A.1 RAM GUIDANCE PUBLICATIONS AND RAM TOOLS}

Endrenyi, J. 1978. Reliability Modeling in Electric Power Systems. John Wiley \& Sons, New York.

The Institute of Electrical and Electronics Engineers (IEEE), Inc. 1987. IEEE Guide for General Principles of Rel iability Analysis of Nuclear Power Generating Station Protection Systems. IEEE Std. 352-1987, New York.

Joy, D. S. 1989. Documentation and User's Guide - Systems Integration Operations/Logistics Model (SOLMOD) Version 2.1. Oak Ridge National Laboratory, Oak Ridge, Tennessee.

Kingsbury, R. J., et a1. March 1980. "Methodology to Aid in Preparing Engineering Design Criteria for a Nuclear Waste Repository Equipment and Processes: Task Summary Report for Conceptual Study Review and Functional Flow Diagram Development." Los Alamos Technical Associates, Inc., Los Alamos, New Mexico.

Lakner, A. A., and R. T. Anderson. 1985. Reliability Engineering for Nuclear and Other High Technology Systems. Elsevier Applied Science Publishers, Essex, England, pp. 119-120.

McCormick, N. J. 1981. Reliability and Risk Analysis. Academic Press, New York, pp. 91-116.

Martin Marietta Energy Systems (MMES), Inc. 1985. AVLIS Reliability, Availability, and Maintainability Program Plan. JID 85-37, Oak Ridge, Tennessee, pp. 26-28.

Nuclear Energy Agency/Organization for Economic Cooperation and Development (NEA/OECD). June 1990. "Index of Radioactive Waste Management Computer Programs." Nuclear Waste Bulletin, pp. 56-61.

Ouderkirk, S. J. 1988. WASTES-II: Waste System Transportation and Economic Simulation Release 24 User's Guide. PNL-5714, Pacific Northwest Laboratory, Richland, Washington.

Palisade Corporation. 1988. QRISK. Newfield, New York.

Pegden, C. D. July 1985. Introduction to SIMAN with Version 3.0

Enhancements. Systems Modeling Corporation, State College, Pennsylvania. 
Schriber, T. J. 1974. Simulation Using GPSS. John Wiley and Sons, New York.

Shooman, M. L. 1968. Probabilistic Reltabiltty: An Engineering Approach. McGraw-Hi11 Book Company, New York.

Sovers, R. A. 1987. RAMSIM/NWSI - Nuclear Waste System Integration

Reliability, Avallability Simulation Model. PNL-5980, Pacific Northwest Laboratory, Richland, Washington.

U.S. Department of Defense (DOD). 1977. Military Standard: Reliability. Design Qualification and Production Acceptance Tests: Exponential Distribution. MIL-STD-781C, U.S. DOD, Washington, D.C.

U.S. Department of Defense (DOD). 1977. Military Standard: Reltabillty Growth Testing. MIL-STD-1635(EC), U.S. DOD, Washington, D.C.

U.S. Department of Defense (DOD). 1980. Reliability Program for Systems and Equipment Development and Production. MIL-STD-785B, U.S. DOD, pp. A-12-13, $201-1$.

Von Alven, W, 1964. Rellability Engineering. Prentice-Ha17, Inc., Englewood Cliffs, New Jersey.

\section{A.2 SOURCES OF RAM DATA}

Government-Industry Data Exchange Program (GIDEP). April 1989. ReliabilityMaintainability (R-M) Analyzed Data Summaries. GIDEP Operation Center, Corona, California.

Government-Industry Data Exchange Program (GIDEP). December 1990. Index of Reports for December 1990. GIDEP Operation Center, Corona, California.

North American Electric Reliability Council, Generating Availability Data System (NAERC). 1988. Generating Availability Report, 1983-1987. Princeton, New Jersey.

U.K. Atomic Energy Authority (UKAEA). 1979. National Center of Systems Reliability Data Book, Volume 2. U.K. Atomic Energy Agency, Warrington, England.

U.S. Department of Energy (DOE). 1990. Spent Fuel Storage Requirements 1990. 2040. DOE/RL-90-44, DOE Field Office, Richland, Washington.

Verna, B. J., ed. 1990. "Nuclear Power Experience." Nuclear Power Experience, Inc., Encino, California.

Walling, R. C., C. M. Heeb, and W. L. Purcell. 1988. Reactor-Specific Spent Fuel Discharge Projections: 1987 to 2020. PNL-6430, Pacific Northwest Laboratory, Richland, Washington. 


\section{A.3 SURVEY CONTACTS}

Battelle Paciffc Northwest Laboratory:

Lavel le L. Clark

Cody J. Hostick

Robert W. Mckee

Paul T. Ot is

Steven M. Short

Thomas W. Wood

Bechte1 Group, Inc.; Special Operations,

Engineering Technology:

Larry Damon, Manager

COGEMA, Inc.:

Amour Kouakou

Electric Power Research Institute:

Ray Lambert

Boyer Chu

General Electric Corporation;

Morris Operation:

T. E. Inge1s, Plant Manager

James Kesman, O\&M Manager

MITRE Corporation:

Douglas M. Medvilie

Frederick J. Klingener

NUMATEC, Inc.:

Giles David

Meile Miller

Ralph M. Parsons Company:

Richard Burke

Joseph Chang

Vincent Ho

Anita Jowdy

Herbert Saffell

Nate Snyder

Lone-Yee Yee

Westinghouse Electric Corporation,

West Valley Nuclear Services Company;

Systems Engineering:

Fuel Program:

Peter Burn

Fred Dammerow

Bernard Conners, Manager

Todd Cotter 
APPENDIX B

RAM CALCULATION SAMPLE RESULTS 


\section{APPENDIX B}

\section{RAM CALCULATION SAMPLE RESULTS}

System-level RAM calculations were performed, using an existing lowcomplexity computer model to study the effects of differing facility reliability levels on other facilities that must perform in series in the waste management system.

PNL created a system-level RAM computational model using existing commercial software, SIMAN (Pegden 1985), to perform the system level RAM analysis. The model was kept as simple as possible, including only a. "Level O" description of the basic system, as described in System Description of the Basic MRS System for the FY 1990 Systems Integration Program Studies (Mckee et a1. 1990). The basic monitored retrievable storage (MRS) system is shown in Figure B.1, and the derived model used in the present analysis is shown in Figure B.2.

The model system's major elements include waste generators, waste generator-to-MRS transportation [PWR (pressurized water reactor) raf1, BWR (boiling water reactor) rail, PWR truck, and BWR truck options], wastegenerator-to-repository transportation (MRS bypass), the MRS, MRS-torepository transportation (rail transport only), and the repository.

The basic MRS and non-MRS (repository only) systems have previously been modeled and analyzed with spent fuel throughput rates ranging from 3,000 to 6,000 MTU per year (Clark and Myers 1989). For this study, a nominal shipping rate of 2,200 MTU per year from waste generators was used. This value was derived from the 10-year average annual acceptance allocations for a11 waste generators from OCRWM's Annual Capacity Report (DOE 1990). 


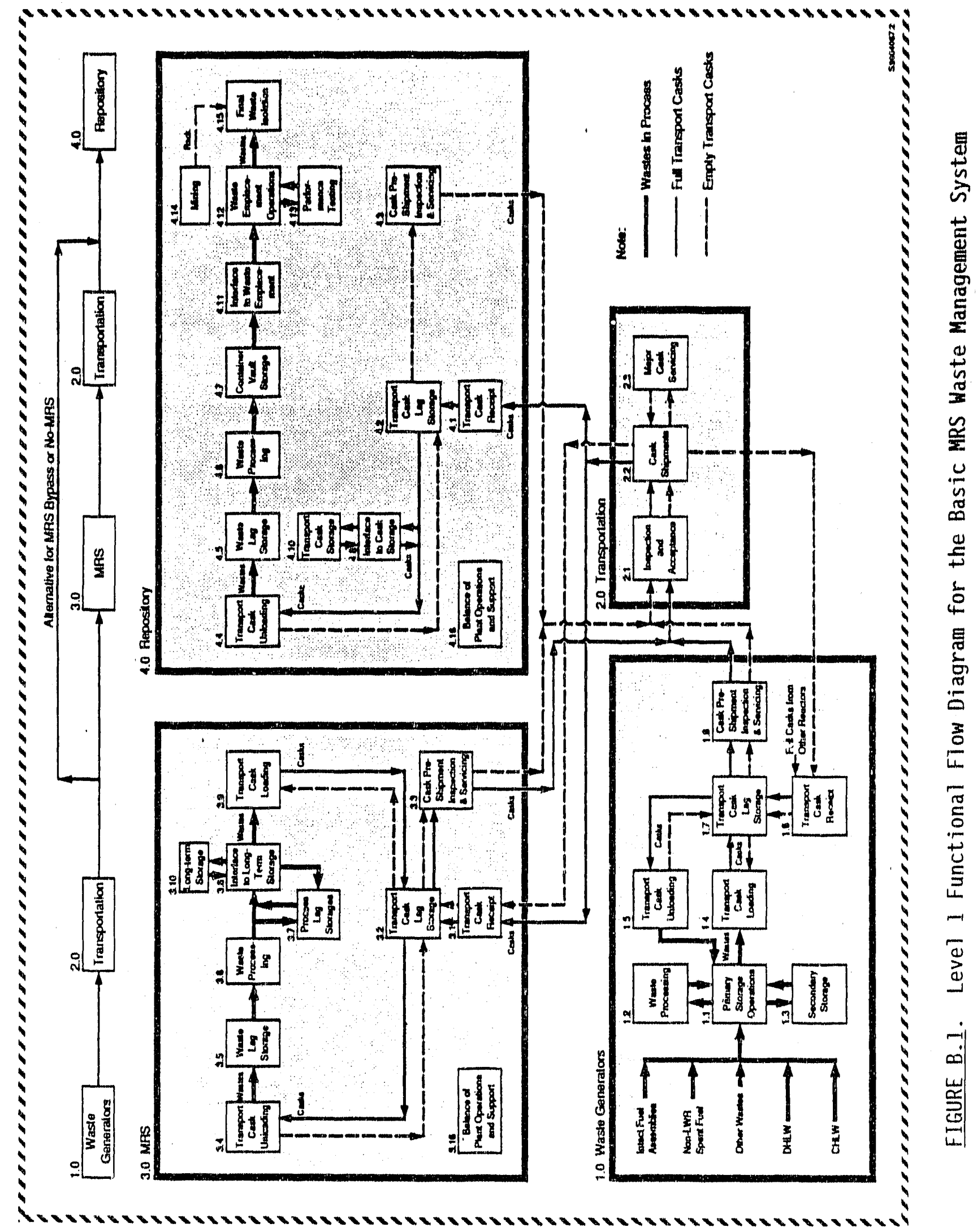

B. 2 

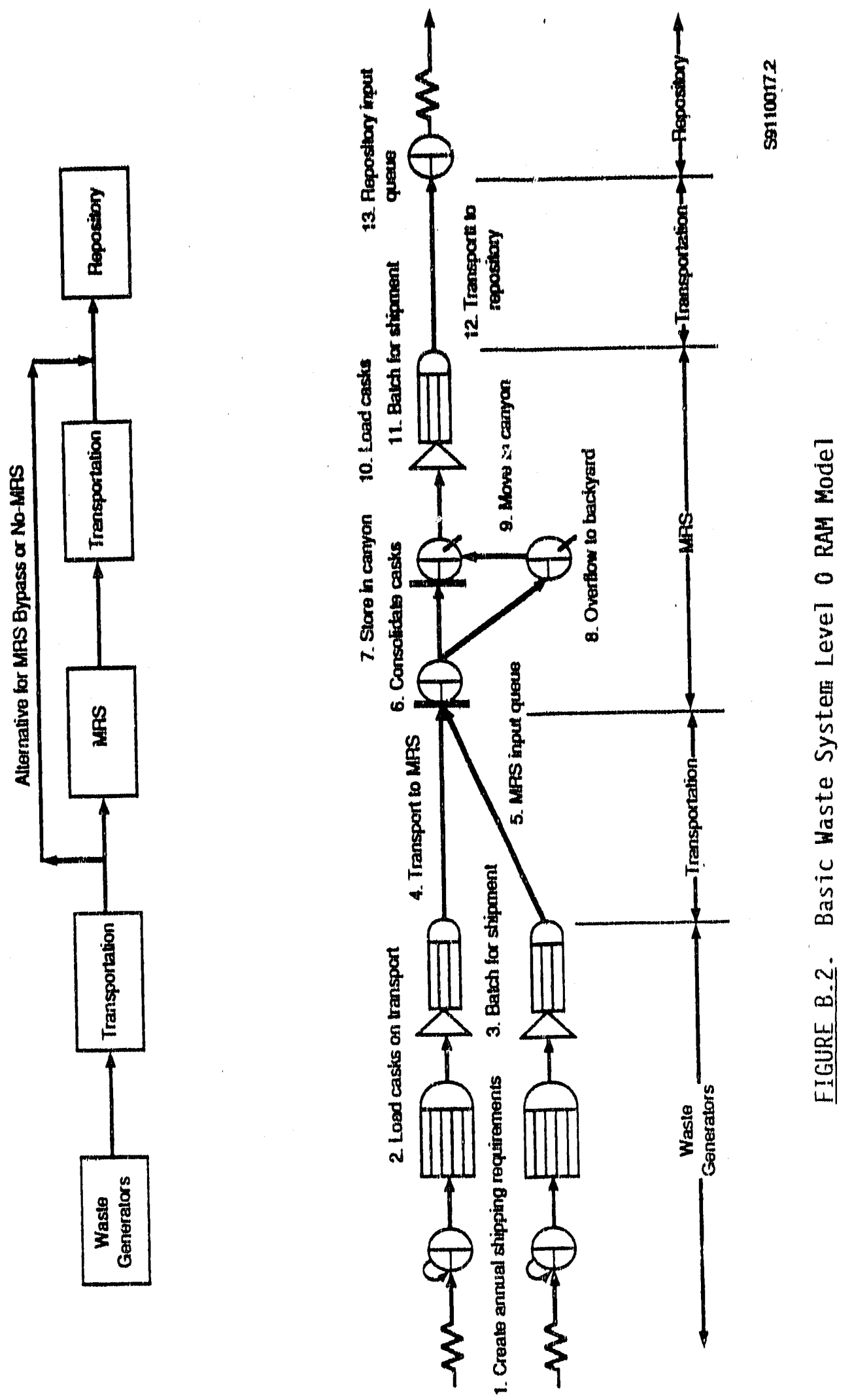

B. 3 
RAM analyses were run for all of the system's factlittites. The effects of factlity avallabilities of from 0 to $100 \%$ for each s,ystem elemerit on all other elements were assessed. Sample results are shown in Figures B.3 through B.6.

In a system with an MRS, low avallability at one facllity need not: affect the processing rate at other factltties for several years if the MRS inventory is maintained roughly midrange between 0 and its legal maximum of 15,000 MTU. For example, Figure B.3 shows that for MRS average annual avallab1lity down to $50 \%$, overall system throughput can be maintained by using MRS bypass transportation. Figure B,4 shows quantitatively that low avallability of shipping from waste generators does not necessartly reduce delivertes to the reposttory. Shortfalls from waste generators can be made up from MRS inveritory unt 11 it is exhausted. Figure B.5 shows that, at a 2,200 MTU/year throughput rate throughout the system, total fallure of shipping from waste generators leads to exhaustion of a 10,000 MTU inventory at the MRS in about 4.5 years (fdling the MRS and the reposttory). Flgure B.6 shows the effects of long-term unavallabllity of the MRS/reposttory transport link. Waste generators could continue to ship 2,200 MTU/year to the MRS for about 2.4 years before the MRS exceeded its legal maxtmum inventory. After that point, a11 shipments from waste generators would have to go directly to the repository.

The present analysis yielded results that are zonsistent with earlier RAM studies of alternative system configurations (a.g., MRS, multiple MRS, and reposttory-orily systems). Though the analysis at the level of detail used in this study produced rather straightforward and intuttive results, it is ciear that system-level RAM analysis can yteld valuable insights on the kinds of issues that are critical to the waste management program (e.g., queue and intertm storage stzes, average and peak inventortes, and other considerations). 


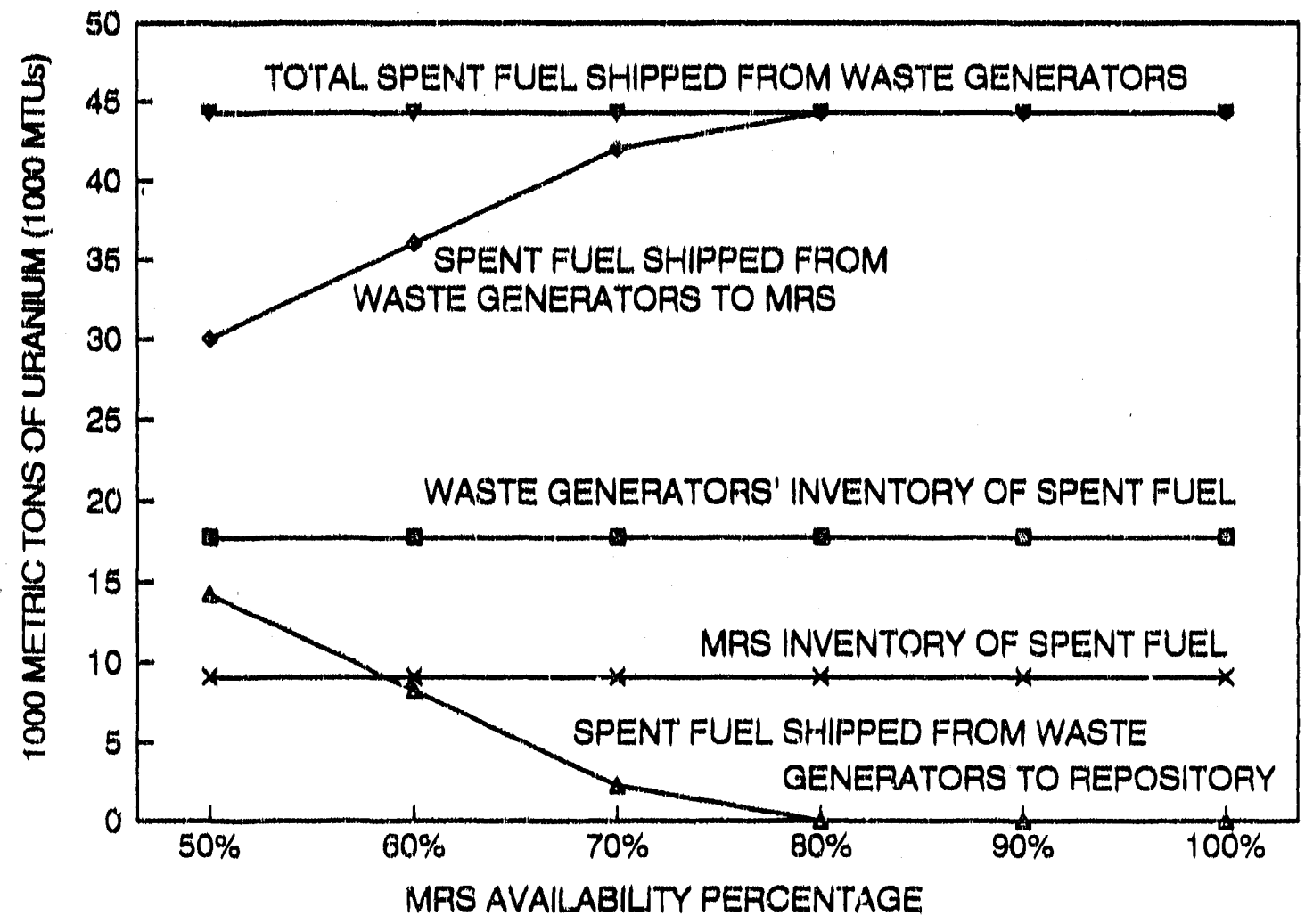

FIGURE DEPICTS SYSTEN STATUS IN 2030 (20 YEARS OF OPERATION)

EIGURE B.3. MRS Availability Analysis

\section{ASSUMPTIONS:}

- MRS opens in 1998 with a maximum capacity of 10,000 MTU

- MRS inventory in 2010 is just under 10,000 MTU

- Repository opens in 2010

- MRS maximum capactty after 2010 i's 15,000 MTU

- $100 \%$ avatlability processing rate is 2,200 MTU/year

- MRS bypass (WG/reposttory transport) used as needed. 


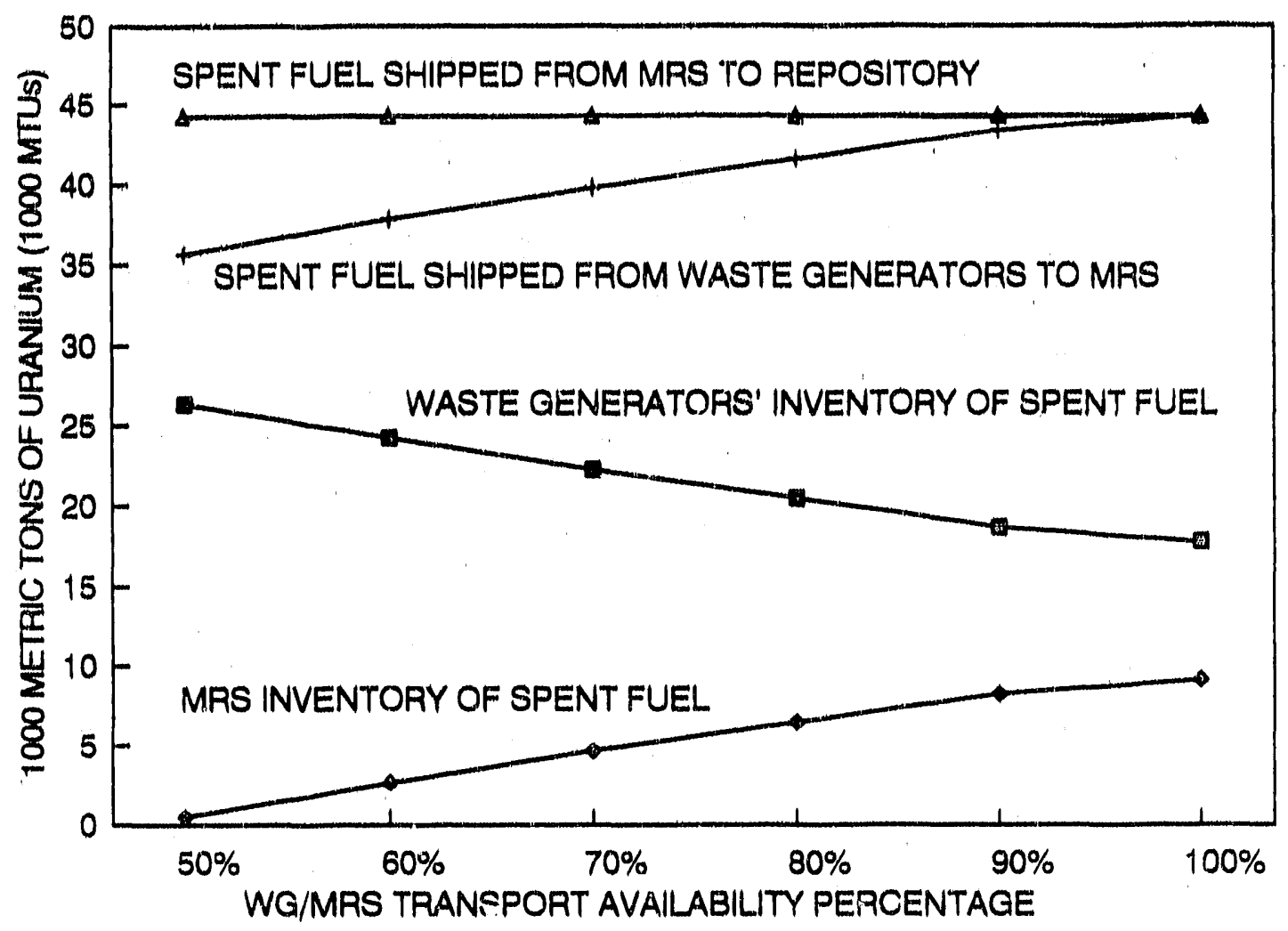

FIGURE DEPICTS SYSTEM STATUS IN 2030 (20 YEARS OF OPERATION)

EIGURE B.4. Waste Generator/MRS Transport Availability Analys is

\section{ASSUMPTIONS :}

- MRS opens in 1998 with a maximum capacity of 10,000 MTU

- MRS inventory in 2010 is just under 10,000 MTU

- Repository opens in 2010

- MRS maximum capacity after 2010 is 15,000 MTU

- "100\% avallability" processing rate is 2,200 MTU/year 


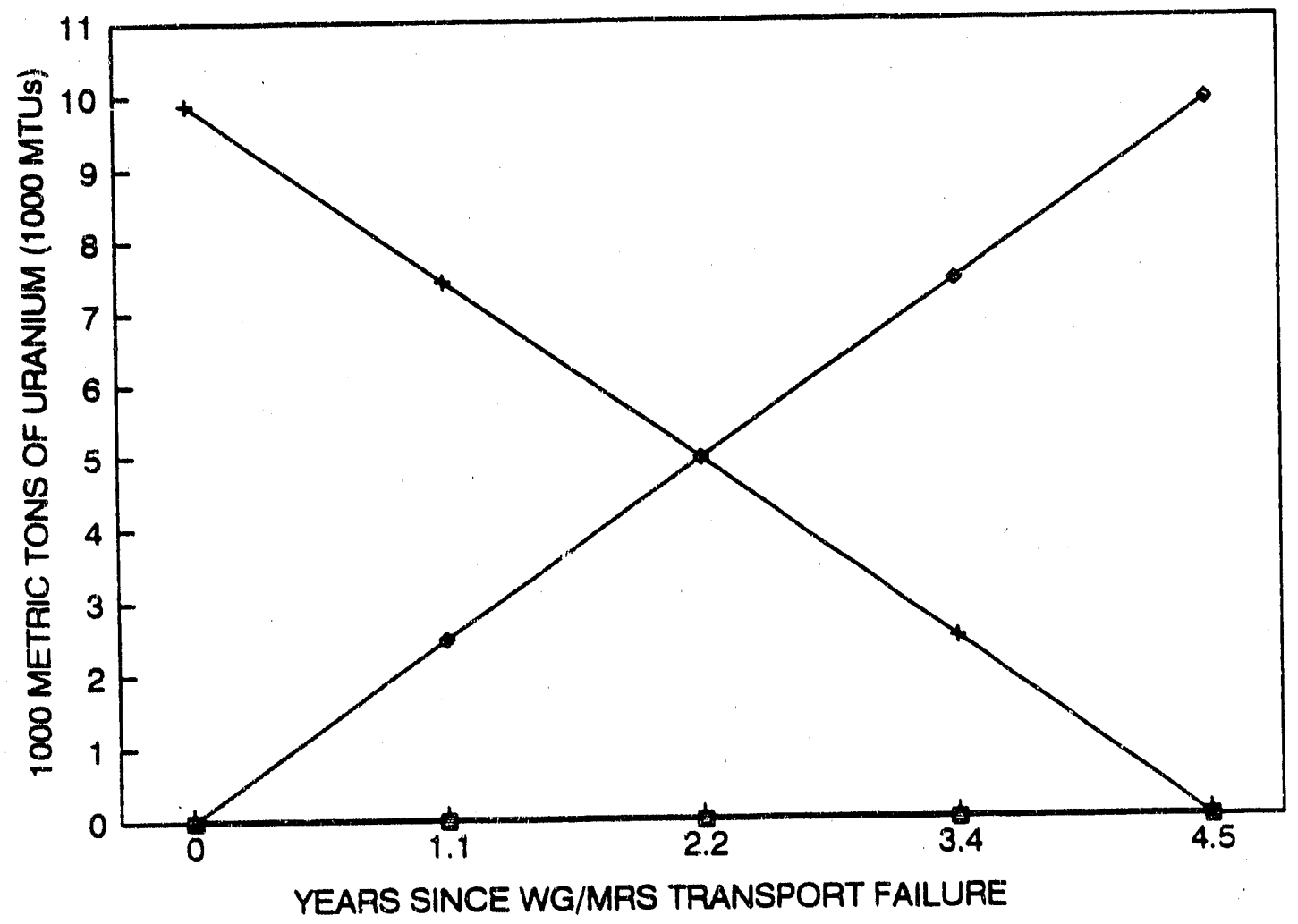

NO MRS BYPASS

- CHANGE IN WASTE GENERATORS' INVENTORY OF SPENT FUEL.

+ MRS INVENTORY OF SPENT FUEL

- SPENT FUEL SHIPPED FROM MRS TO REPOSITORY

FIGURE B.5. Waste Generator/MRS Transport 0\% Availability

\section{ASSUMPTIONS:}

- MRS opens in 1998 with a maximum capacity of 10,000 MTU

- MRS inventory in 2010 is just under 10,000 MTU

- Repository opens in 2010

- MRS maximum capacity after 2010 is 15,000 MTU

- "100\% availability" processing rate is 2,200 MTU/year 


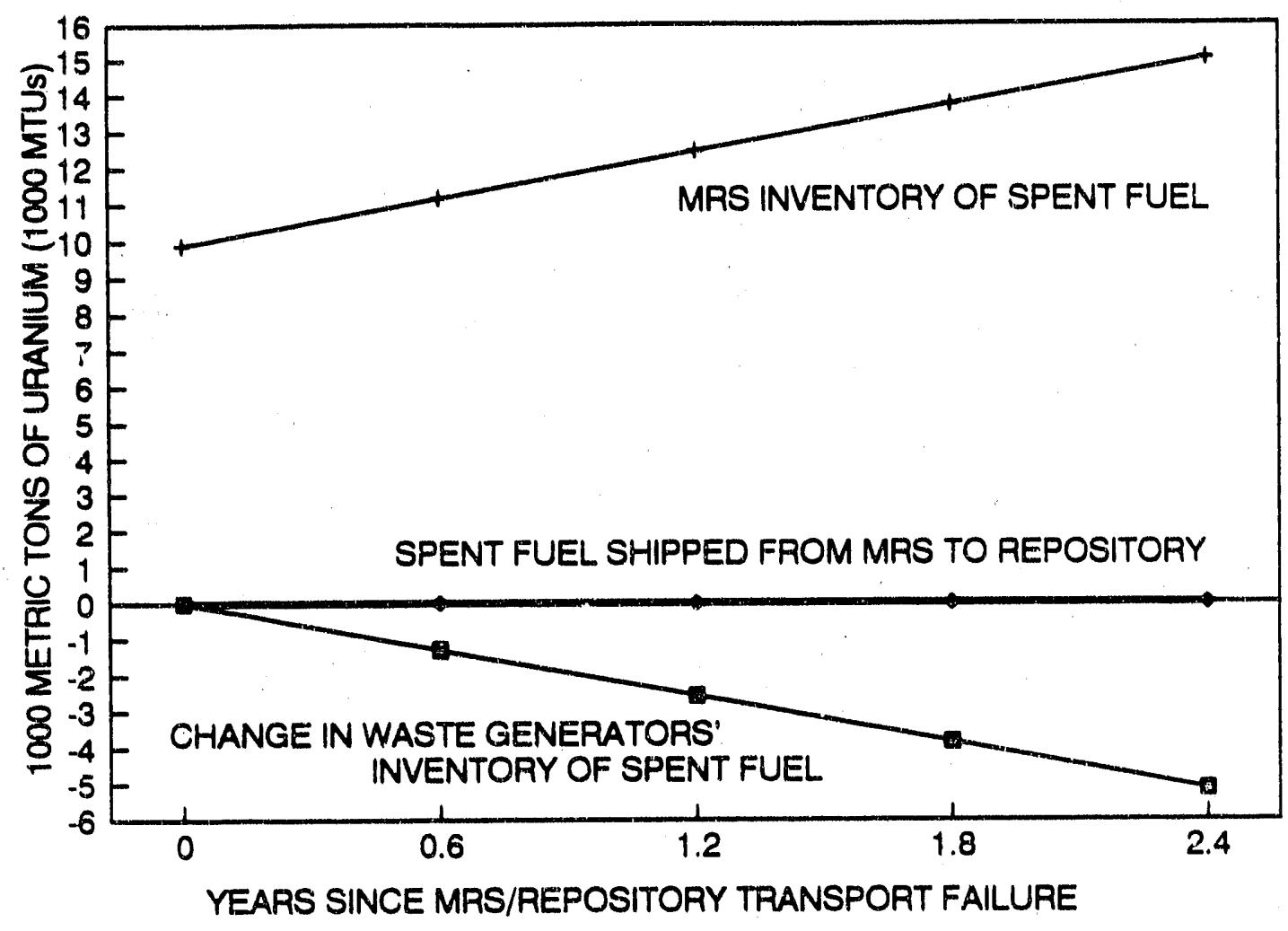

NO MRS BYPASS

FIGURE B.6. MRS/Repository Transport 0\% Availability

\section{ASSUMPTIONS:}

- MRS opens in 1998 with a maximum capacity of 10,000 MTU

- MRS inventory in 2010 is just under 10,000 MTU

- Repository opens in 2010

- MRS maximum capacity after 2010 is 15,000 MTU

- "100\% availability" processing rate is 2,200 MTU/year 


\section{REFERENCES}

Clark, L. L.., and R. S. Myers. 1989. MRS Systems Study Task I Report, Waste Management System Reliability Analysis. PNL-6875, Pacific Northwest Laboratory, Richland, Washington.

Mckee, R. W., J. R. Young, and G. J. Konzek. 1991. System Description of the Basic MRS System for the FY 1990 Systems Integration Program Studies.

PNL-7508, Pacific Northwest Laboratory, Richland, Washington.

Pegden, C. D. 1985. Introduction to SIMAN with Version 3.0 Enhancements. Systems Modeling Corporation, State College, Pennsylvania.

U.S. Department of Energy (DOE). 1990. Annual Capacity Report. DOE/RW-0294, Office of Civilian Radioactive Waste Management, Washington, D.C. 


\section{DISTRIBUTION}

No. of

Copies

\section{OFFSITE}

12 DOE/Office of Scientific and Technical Information

12 Office of Civilian Radioactive Waste Management

U.S. Department of Energy 1000 Independence Ave., SW Washington, DC 20545

ATTN: J. Carlson, RW-40

R. Blaney, RW-4

A. Brownste in, RW-40

W. Danker, RW-4

S. Gomberg, RW-322

T. Isaacs, RW-43

W. Lemeshewsky, RW-30

R. Milner, RW-40

T. Nguyen, RW-321

T. Pollog, RW-40

J. Saltzman, RW-5

J. Williams, RW-40

3 Yucca Mountain Project Office

U.S. Department of Energy

P.0. Box 98518

Las Vegas, NV 89183-8518

ATTN: M. Cloninger

C. Gertz

G. Rodriguez

2 Battelle Washington Operations 370 L'Enfant Promenade

Suite 900

Washington, DC 20024-2115

ATTN: C. Mackay

J. Strah1

2 Sandia National Laboratory

Division 6311

Albuquerque, NM 87105

ATTN: A. Dennis

G. Hertel
No. of

Copies

4 Roy $F$. Weston, Inc.

955 L'Enfant Plaza, SW

Washington, DC 20024

ATTN: N. Dayem

J. DiNunno

M. Conroy

J. Lilly

3 E. R. Johnson \& Associates, Inc.

10461 White Granite Dr.

Suite 204

0akton, VA 22124

ATTN: B. Cole

E. Johnson

N. McLeod

2 Lawrence Livermore National Laboratory

P.0. Box 806

Livermore, CA 94550

ATTN: L. Ballou

M. Revelli

JK Associates

1001 Spring Street

Suite 406

Silver Spring, MD 20910

ATTN: T. Cotton

5 Bristlecone Environmental

Technology Corp.

11673 Newbridge Court

Reston, VA 22091-3515

3 TRW Environmental Safety

Systems, Inc.

2650 Park Tower Drive

Vienna, VA 22180

ATTN: D. Buxton

P. Gottlieb

S. Willis 
No. of

Copies

Oak Ridge National Laboratory P.0. Box $X$

Oak Ridge, TN 37830

ATTN: D. Joy

2 DOE Richland Field office

D. C. Langstaff

J. J. Sutey
No. of

Copies

15 Pacific Northwest Laboratory

S. Q. Bernnett

G. J. Konzek

M. R. Kreiter

R. W. McKee

G. W. McNair

M. R. Shay

S. R. Short

R. I. Smith

S. A. Vance

Publishing Coordination

Technical Report Files (5) 

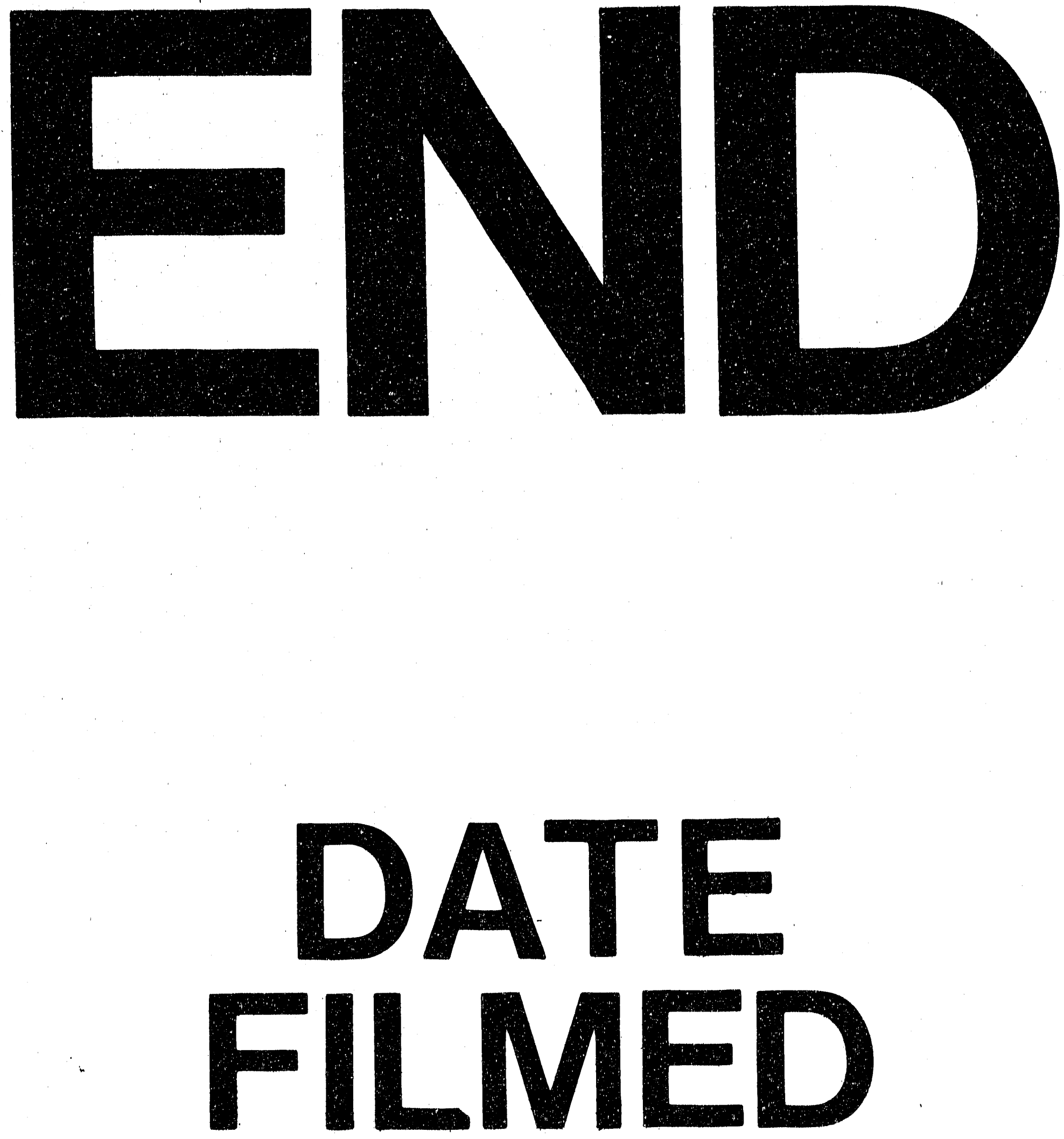

3

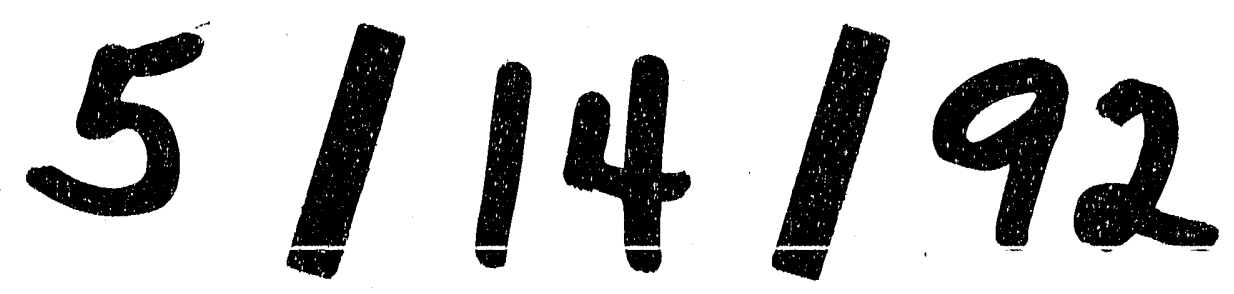


